\title{
. \\ Gut Microbiota and Complications of Type-2 Diabetes
}

\author{
Camelia Oana Iatcu ${ }^{1,2}$, Aimee Steen ${ }^{3}\left[\right.$ and Mihai Covasa ${ }^{1,3, *}$ \\ 1 College of Medicine and Biological Sciences, Stefan cel Mare University of Suceava, 720229 Suceava, Romania; \\ oana.iatcu@usm.ro \\ 2 College of Medicine, "Grigore T. Popa" University of Medicine and Pharmacy, 700115 Iasi, Romania \\ 3 Department of Basic Medical Sciences, College of Osteopathic Medicine, Western University of \\ Health Sciences, Pomona, CA 91766, USA; aimee.steen@westernu.edu \\ * Correspondence: mcovasa@westernu.edu
}

Citation: Iatcu, C.O.; Steen, A.; Covasa, M. Gut Microbiota and Complications of Type-2 Diabetes. Nutrients 2022, 14, 166. https:// doi.org/10.3390/nu14010166

Academic Editors: Laura Soldati and Luigi Barrea

Received: 7 December 2021

Accepted: 29 December 2021

Published: 30 December 2021

Publisher's Note: MDPI stays neutral with regard to jurisdictional claims in published maps and institutional affiliations.

Copyright: (c) 2021 by the authors. Licensee MDPI, Basel, Switzerland. This article is an open access article distributed under the terms and conditions of the Creative Commons Attribution (CC BY) license (https:// creativecommons.org/licenses/by/ $4.0 /)$.

\begin{abstract}
The gut microbiota has been linked to the emergence of obesity, metabolic syndrome and the onset of type 2 diabetes through decreased glucose tolerance and insulin resistance. Uncontrolled diabetes can lead to serious health consequences such as impaired kidney function, blindness, stroke, myocardial infarction and lower limb amputation. Despite a variety of treatments currently available, cases of diabetes and resulting complications are on the rise. One promising new approach to diabetes focuses on modulating the gut microbiota with probiotics, prebiotics, synbiotics and fecal microbial transplantation. Differences in gut microbiota composition have been observed in preclinical animal models as well as patients with type 2 diabetes and complications such as diabetic nephropathy, diabetic retinopathy, diabetic neuropathy, cerebrovascular disease, coronary heart disease and peripheral artery disease compared to healthy controls. Severity of gut microbiota dysbiosis was associated with disease severity and restoration with probiotic administration in animal models and human patients has been associated with improvement of symptoms and disease progression. Characterizing the gut microbiota dysbiosis in different diseases and determining a causal relationship between the gut microbiota and disease can be beneficial in formulating therapeutic interventions for type 2 diabetes and associated complications. In this review, we present the most important findings regarding the role of the gut microbiota in type 2 diabetes and chronic complications as well as their underlying mechanisms.
\end{abstract}

Keywords: gut microbiota dysbiosis; diabetes complications; retinopathies; nephropathies; microvascular complications; macrovascular complications

\section{Introduction}

The gut microbiota is a complex ecosystem made up of a community of microorganisms that include trillions of bacteria spanning at least 1000 different species [1]. The gut microbiota is predominantly composed of bacteria but also contains other commensals such as archaea, viruses, fungi and protists [2]. All of these components are both relevant and important in understanding the relationship between the gut microbiota and the host.

Dysbiosis of the gut microbiota is primarily characterized by decreased diversity and abundance of bacteria and fungi, especially those associated with dysfunction and various pathologies [3]. Chief among them are cardiovascular, neuronal, immune and metabolic disorders [4] through the influence of bile acid metabolism, inflammatory status, insulin resistance and incretin secretion. This can lead to the emergence of obesity [5], metabolic syndrome and the onset of type 2 diabetes [6,7] through decreased glucose tolerance and insulin resistance [8]. The gut microbiota is an important player in chronic systemic inflammation secondary to endotoxemia caused by the release of endotoxins following bacterial death [9]. While the link between the gut microbiota and the onset and progression of diabetes is still under investigation, several studies to date have focused on the pathophysiology of diabetes, with few of them investigating the role of the gut 
microbiota in diabetes complications. This review summarizes the most important findings regarding the role of the gut microbiota in type 2 diabetes and describes its role on potential pathways that lead to chronic complications of diabetes. Modulation of the gut microbiota through the use of prebiotics, probiotics, synbiotics and fecal microbiota transplantation to restore metabolic deficits associated with these pathologies is also discussed.

\section{Gut Microbiota, Type 2 Diabetes and Its Complications}

Type 2 diabetes, like cardiovascular disease, cancer and chronic respiratory disease, is considered a chronic and noncommunicable disease responsible for $80 \%$ of premature deaths globally [10]. As of 2019, there were approximately 463 million cases of diabetes worldwide with an estimated 700 million by the year 2045 if current trends continue despite the variety of pharmacological interventions currently available [11].

Diabetes is characterized by high blood sugar levels that occur as a result of decreased pancreatic insulin production or decreased insulin sensitivity in tissues that typically respond to insulin signaling [12]. Poorly controlled diabetes and metabolic disorders associated with type 2 diabetes such as impaired lipid metabolism, the presence of oxidative stress and hypertension [13] can lead to both microvascular and macrovascular complications. Some microvascular complications of type 2 diabetes that involve small blood vessels include diabetic nephropathy, diabetic neuropathy and diabetic retinopathy. Conversely, common macrovascular complications that involve large blood vessels include cerebrovascular disease, coronary heart disease and peripheral vascular disease [14]. Other macrovascular complications of poorly controlled diabetes include congestive heart failure, impaired lipid metabolism, stroke, organ inflammation, weight gain, peripheral vascular disease and electrolyte imbalance [15].

Changes in interdependent metabolic pathways have also been observed in association with type 2 diabetes [16]. For example, coronary heart disease caused by impaired insulin metabolism can lead to dyslipidemia which is a risk factor for cardiovascular complications of diabetes [17]. Other specific factors known to contribute to the progression of diabetes complications include increased reactive oxygen species (ROS), chronic hyperglycemia and decreased antioxidant status [18]. The presence of these complications also leads to an overall decline in quality of life and an increase in mortality rate [19].

A plethora of studies have demonstrated a significant association between changes in the composition profile of gut microbiota and development of diabetes. In particular, perturbed Bacteroidetes/Firmicutes phylum eubiosis has been linked with increased intestinal permeability, with infiltration of bacteria byproducts through a leaky gut barrier triggering subsequent inflammatory responses characteristic of diabetes. On the other hand, several bacteria have been shown to exert a protective role by decreasing the risk of diabetes development through reduction in proinflammatory markers and maintaining intestinal barrier integrity. For example, Lactobacillus fermentum, plantarum and casei, Roseburia intestinalis, Akkermansia muciniphila and Bacteroides fragilis have all been shown to improve glucose metabolism and insulin sensitivity, and suppress proinflammatory cytokines. Notably, some drugs such as metformin which is commonly used for diabetes treatment have also been shown to alter the composition of the gut microbiota, suggesting that metformin interacts with the gut microbiota through modulation of inflammation, glucose homeostasis, gut permeability and short-chain fatty acid-producing bacteria [20]. Additionally, in patients with diabetes-associated gut dysbiosis, metformin promotes butyrate and propionate production, improving a patient's ability to catabolize amino acids [21]. These changes coupled with increased levels of Akkermansia in the gut may contribute to the effects of metformin on glucose metabolism [22]. It appears that the metabolic factors associated with chronic low-grade inflammation and oxidative stress, which link gut microbiota dysbiosis and type 2 diabetes, are the same ones that influence the onset and progression of diabetic complications $[23,24]$. This relationship gives credence to the concept that modulation of the gut microbiota may be a promising strategy in the management of diabetes and associated complications as presented in the following sections. 


\subsection{Gut Microbiota in Diabetic Nephropathy}

Diabetic nephropathy occurs in approximately $40 \%$ of patients with poorly managed diabetes [25], of which approximately $20 \%$ are hemodialysis patients [26], leading to end-stage renal disease, as well as cardiovascular complications [27]. Recent increases in the number of diabetic nephropathy and end-stage renal disease cases have been attributed to modern societal habits and lifestyle risks associated with diabetes and hypertension [28,29]. Similarly, increased stress on the kidneys due to hyperglycemia can lead to diabetic nephropathy as well as associated systemic inflammation, micro and macro albuminuria and proteinuria $[30,31]$. In addition, other factors such as genetics, age, obesity, high blood pressure and dyslipidemia [32,33] all have been shown to contribute to the progression of diabetic nephropathy. More recently, however, several studies have shown that dysbiosis of the gut microbiota can play a role in the development of chronic kidney disease [34]. In particular, the products of bacterial metabolism have been shown to influence the occurrence and progression of chronic kidney disease [35] while progression to renal failure lead to worsening of gut microbiota dysbiosis [36].

For example, the composition of the gut microbiota differs in both animals and people with chronic kidney disease. In studies using animals and humans with chronic kidney disease there was a decrease in the proportion of Bifidobacterium [37], Bactemides [38] and Lactobacillus [36]. Moreover, in patients with chronic kidney disease a decrease in the proportion of Prevotella [39,40], Ruminococcaceae, Roseburia, Faecalibacterium [40] and an increase in the proportion of Parabacteroides [39], Enterococcus [40], Enterobacteriaceae [36] and Klebsiella [40] have been reported. The increased proportions of Bacterioidaceae and Clostridiaceae in patients with chronic kidney disease have been associated with systemic inflammation [41]. In contrast, bacteria such as Lactobacillaceae, Prevotellaceae and Bifidobacteriacea [36], that are associated with anti-inflammatory effects and protecting intestinal barrier integrity were less represented in patients with chronic kidney disease [41]. In general, patients with chronic kidney disease show a decreased proportion of anaerobic bacteria [42]. Furthermore, bacterial DNA was present in the blood of $20 \%$ of patients with chronic end-stage renal disease who were not on dialysis. In these patients, the same bacterial genus was detected in their intestines along with increased biomarkers of low-grade inflammation [43].

Given that the imbalance of the gut microbiota influences many chronic diseases including type 2 diabetes and its complications, it follows that balancing the composition of the gut microbiota could be a strategy for controlling or even preventing disease. Some studies have analyzed the effects of probiotics $[42,44]$ or synbiotics in modulating the gut microbiota in patients with chronic kidney disease $[45,46]$. In a clinical trial conducted in patients with stage 3 and stage 4 chronic kidney disease, urea nitrogen in the blood and uric acid concentration decreased after administering a mixture of Lactobacillus acidophilus, Streptococcus thermophilus and Bifidobacterium longum for six months [42]. In a similar study, the level of uric nitrogen in the blood also decreased after administration of dairy products containing Lactobacillus for two months [47]. When the effects of probiotics were tested in patients with chronic kidney disease on dialysis, administration of Lactobacillus acidophilus improved blood levels of dimethylamine and nitrodimethylamine [48], as well as lowered the level of dimethylamine and nitrosodimethylamine, a known carcinogen [49]. A summary of results of clinical trials examining the effects of probiotic intake in patients with type 2 diabetes and kidney disease is presented in Table 1 . Thus, research has delineated specific changes in the gut microbiome associated with diabetic nephropathy as well as physiologic mechanisms underlying changes resulting from probiotic or symbiotic supplementation in patients with diabetic nephropathy. 
Table 1. Effects of probiotics on type 2 diabetes and kidney disease.

\begin{tabular}{|c|c|c|c|c|c|}
\hline Reference & Design & $\begin{array}{l}\text { Probiotic } \\
\text { Source }\end{array}$ & Probiotic Dose, CFU & $\begin{array}{l}\text { Study Period } \\
\quad(w k / d)\end{array}$ & Effects \\
\hline$[50]$ & $\mathrm{RD}, \mathrm{DB}, \mathrm{CT}$ & tablet & $\begin{array}{l}\text { L. acidophilus strain } \\
\text { ZT-L1, } \\
\text { B. bifidum strain ZT-B1, } \\
\text { L. reuteri strain ZT-Lre, } \\
\text { L. fermentum strain } \\
\text { ZT-L3 } \\
8 \times 10^{9} \mathrm{CFU} / \mathrm{d}\end{array}$ & $12 \mathrm{wk}$ & $\begin{array}{c}\mathrm{S} \downarrow \text { FG, I, HOMA-IR, TG, } \\
\text { VLDL, TC/HDL-C ratio, } \\
\text { hs-CRP, MDA, AGEs, } \\
\text { BUN, creatinine, urine } \\
\text { protein } \\
\text { S } \uparrow \text { QUICKI, HDL-C, } \\
\text { GSH, CG } \\
=\text { HbA1c, LDL-C, NO, } \\
\text { TAC }\end{array}$ \\
\hline [51] & $\mathrm{RD}, \mathrm{DB}, \mathrm{CT}$ & soy milk & L. plantarum A7 & $8 w k$ & $\begin{array}{c}\text { S } \downarrow \text { albuminuria, serum } \\
\text { creatinine, serum } \\
\text { interleukin-18, serum } \\
\text { sialic acid } \\
\text { S improvment in } \\
\text { estimated GFR }\end{array}$ \\
\hline [52] & $\mathrm{RD}, \mathrm{DB}, \mathrm{CT}$ & capsule & $\begin{array}{l}\text { L. acidophilus } \\
\text { L. casei } \\
\text { B. bifium }\end{array}$ & $12 \mathrm{wk}$ & $\begin{array}{c}\text { S } \downarrow \text { FG, I, HOMA-IR, } \\
\text { HbA1c, hs-CRP, MDA, } \\
\text { SGA score, TIBC } \\
\text { S } \uparrow \text { QUICKI } \\
\text { =HOMA-B, TG, VLDL, } \\
\text { CT, LDL-C, HDL-C, NO, } \\
\text { TAC, GSH, GFR, } \\
\text { creatinine, BUN, } \\
\text { albumin, Na, K }\end{array}$ \\
\hline [53] & $\mathrm{RD}, \mathrm{DB}, \mathrm{CT}$ & honey & $\begin{array}{c}\text { Bacillus coagulans T4 } \\
\text { (IBRC-N10791) } \\
10^{8} \mathrm{CFU} / \mathrm{g}\end{array}$ & $12 \mathrm{wk}$ & $\begin{array}{c}\mathrm{S} \downarrow \text { I, HOMA-IR, } \\
\text { CT } / \text { HDL-C ratio, } \\
\text { hs-CRP hs-CRP, MDA, } \\
\text { creatinine } \\
\text { S } \uparrow \text { QUICKI } \\
=\text { FG, TG, VLDL, CT, } \\
\text { LDL-C, HDL-C, NO, } \\
\text { TAC, GSH, BUN }\end{array}$ \\
\hline [54] & $\mathrm{RD}, \mathrm{DB}, \mathrm{CT}$ & soy milk & $\begin{array}{c}\text { L. plantarum A7 } \\
2 \times 10^{7} \mathrm{CFU} / \mathrm{mL}\end{array}$ & $8 w k$ & $\begin{array}{c}\mathrm{S} \downarrow \text { Cys-C, PGRN, NGAL } \\
=\text { sTNFR1 }\end{array}$ \\
\hline [55] & $\mathrm{RD}, \mathrm{DB}, \mathrm{CT}$ & soy milk & $\begin{array}{c}\text { L plantarum A7 (KC } \\
355240, L A 7) \\
2 \times 10^{7} \text { CFUmL }\end{array}$ & $8 \mathrm{wk}$ & $\begin{array}{c}\mathrm{S} \uparrow \text { Glutathione, } \\
\text { Glutathione peroxidase, } \\
\text { Glutathione reductase } \\
\text { S } \downarrow \text { Oxidized glutathione } \\
=\mathrm{MDA}, 8 \text {-iso-PGF2a, } \\
\text { TAC }\end{array}$ \\
\hline
\end{tabular}

RD, randomized; DB, double-blind; CT, clinical trial; T2DM, type 2 diabetes mellitus; L., Lactobacillus, B. Bifidobacterium; CFU, colony-forming units; wk, weeks; d, days; FG, fasting glucose fasting blood glucose, fasting plasma glucose, glycemia, fasting blood sugar; $\mathrm{HbA1c}$, hemoglobin $\mathrm{A} 1 \mathrm{c}$; I, serum insulin concentration, insulin concentration, serum insulin level, insulin; HOMA-IR, homeostasis model of assessment-estimated insulin resistance; QUICKI, quantitative insulin sensitivity check index; TG, triglycerides; VLDL, very-low-density lipoprotein; TC, total cholesterol; HDL-C, high-density lipoprotein; LDL-C, low-density lipoprotein; hs-CRP, high-sensitivity $\mathrm{C}$-reactive protein; $\mathrm{NO}$, nitric oxide; $\mathrm{TAC}$, total antioxidant capacity; $\mathrm{GSH}$, total glutathione; MDA malondialdehyde; AGEs, advanced glycation end products; BUN, blood urea nitrogen; CG, Cockcroft-Gault formula to estimate creatinine clearance; HOMA-B, homeostasis model of assessment-estimated b-cell function; GFR, glomerular filtration rate; SGA, subjective global assessment; TIBC, total iron binding capacity; $\mathrm{Na}$, sodium $\mathrm{K}$, potassium; Cys-C, cystatin C; PGRN, Progranulin; NGAL, neutrophil gelatinase-associated lipocalin; sTNFR1, soluble tumor necrosis factor receptor 1; 8-iso-PGF2a, 8-iso-prostaglandin F2 alpha; =, non significan; S, significant; $\uparrow$, increase; $\downarrow$, decrease. 


\subsection{Gut Microbiota in Diabetic Retinopathy}

In poorly controlled diabetes, the pressure inside the eye increases, and the accumulation of glucose in blood vessels can affect the health of the eye [15]. These processes are associated with microvascular complications in the eye including cataracts, glaucoma and retinopathy [56]. Diabetic retinopathy is a complication of poorly controlled diabetes that can result in blindness over time [57]. Increased activation of retinal microglia and infiltration of immune cells into the retina were found in diabetic retinopathy [58]. In addition, increased oxidative stress and inflammation can result in impaired functions of the renin-angiotensin system leading to metabolic disorders, including diabetic retinopathy [59-65]. Finally, gut microbiota dysbiosis have also been linked with development of diabetic retinopathy.

The microbiota differs in composition throughout the body including the eye. For example, the internal eye compartment is sterile, however, the external compartment is exposed to environmental microorganisms [66]. While the overall gut microbiota is predominantly made up of Firmicutes and Bacteroidetes [67], the microbiota on the ocular surface is composed of primarily Proteobacteria and Actinobacteria [68,69]. In fact, Proteobacteria, Actinobacteria and Firmicutes have been shown to represent over $87 \%$ of all microorganisms present in the eye [70]. Several studies have reported an association between the imbalance of the gut microbiota or the microbiome on the ocular surface and various eye conditions. Furthermore, in humans, a significant decrease in the proportion of Bacteroidetes and Actinobacteria was observed in patients with diabetic retinopathy compared to healthy individuals. Additionally, significant increases in the proportion of Acidaminococcus, Escherichia and Enterobacter appear in the microbiota of patients with diabetic retinopathy compared to healthy controls [71]. Recent research showed a significant decrease in the Mucoromycota thread in patients with diabetic retinopathy compared to individuals without diabetic retinopathy. Likewise, in patients with type 2 diabetes and diabetic retinopathy, a decrease of 12 of the 18 genera present was observed [3]. Microbiota byproducts such as trimethylamine $\mathrm{N}$-oxide (TMAO) derived from dietary choline metabolism have also been linked with diabetes retinopathy. For example, patients with diabetic retinopathy had higher plasma levels of TMAO and proinflammatory cytokines compared to diabetics without retinopathy [72], an effect associated with the severity of the disease. When microbiota composition was analyzed, there was a marked decrease in Pasteurellaceae in diabetic retinopathy [73]. Together, these findings support the concept that specific changes in the gut microbiome and mycobiome are associated with diabetic retinopathy.

Modulation of the gut microbiota profile via administration of probiotics has shown positive effects in preclinical models of diabetic retinopathy. For example, administration of recombinant Lactobacillus paracasei to mice with diabetic retinopathy reduced capillary cell loss and inflammatory expression of cytokines in the retina [74]. Similarly, administration of Lactobacillus paracasei secreting Ang- (1-7) to diabetic mice led to the amelioration of eye disease, by reducing retinal gliosis, inflammation and retinal capillary loss [75]. Lastly, modulation of the gut microbiota in mice with type 1 diabetes by administering Lactobacillus rhamnosus for four months resulted in weight loss, improved blood glucose and reduced intraocular pressure compared to the control group [76]. To date there are no studies investigating the effects of probiotic or symbiotic supplementation on diabetic retinopathy or the effects of modulating the microbiome on diabetic retinopathy in humans.

\subsection{Gut Microbiota in Diabetic Neuropathy}

Chronic uncontrolled diabetes is associated with diabetic neuropathy, a neurodegenerative nutritional disease characterized by damage to peripheral nerves causing pain and numbness [56,77]. The characteristics of diabetic neuropathy are significant decline of peripheral innervations, increased neuronal inflammation, demyelination, axonal atrophy and the diminution of neuronal regenerative capacity [78]. Diabetic neuropathy is present in approximately $50 \%$ of diabetic patients [77] and affects many organs, resulting in various complications such as cardiovascular damage with symptoms of tachycardia, orthostatic 
hypotension, impaired intestinal transit, impaired gastric emptying, profuse sweating and hormonal imbalance. Diabetic peripheral neuropathy has been associated with certain factors, such as oxidative stress, activation of the polyol pathway and inflammation $[79,80]$. Insulin resistance is also implicated in the development of peripheral diabetic neuropathy. While peripheral diabetic neuropathy is a major complication of diabetes, its pathogenesis is not yet fully known.

Diabetic neuropathy has been linked to changes in the diversity of the gut microbiota and the increased presence of pathogens [81]. A comparison of the gut microbiota in patients with diabetic neuropathy, patients with diabetes without diabetic neuropathy and healthy individuals showed an increase in Firmicutes and Actinobacteria as well as a decrease in Bacteroidetes in patients with diabetic nephropathy when compared to patients with diabetes without diabetic neuropathy and healthy individuals. Furthermore, at the genus level, a decrease of Bacteroides and Faecalibacterium and an increase of Escherichia-Shigella, Lachnoclostridium, Blautia, Megasphaera and Rumincoccus torques were observed. It is hypothesized that these changes in the gut microbiota occur as a result of insulin resistance. In addition, elevated levels of Megasphaera have been directly correlated with Homeostatic Model Assessment for Insulin Resistance (HOMA-IR) scores in patients with diabetic neuropathy, which suggests that the presence of insulin resistance is associated with peripheral diabetic neuropathy [81].

Modulation of the gut microbiota by administration of Bifidobacteria and Lactobacillus or fecal transplantation can improve insulin resistance [82]. While several studies have characterized the gut microbiota in patients with diabetic neuropathy, the mechanisms by which gut microbiota acts on the onset and progression of diabetic neuropathy require further investigation. Recent research efforts have investigated the role of the gut microbiota in neurological disorders, including chronic pain [83]. Evidence shows that bacteria can directly activate nociceptors through constituent elements and byproducts [84,85]. For example, toxin produced by Staphylococcus aureus, called $\alpha$-hemolysin, has been shown to induce spontaneous pain [86]. In patients with peripheral diabetic neuropathy, the presence of Parabacteroidetes is associated with amelioration of metabolic disorders and is positively correlated with CRP and Tauroursodeoxycholic acid (TUDCA) levels [81]. Additionally, the presence of Parabacteroidetes and changes in TUDCA levels may influence insulin resistance and the onset of dyslipidemia, which in turn affect the onset of peripheral diabetic neuropathy [81].

It is known that modulation of the gut microbiota can influence the central and peripheral nervous system, in a bidirectional matter through gut-microbiota-brain axis [83]. There are currently no pharmacological interventions available to treat diabetic neuropathy and the associated decline in quality of life that it may cause. Because of this, further research is required to investigate the effects of taking probiotic or synbiotic dietary supplements to prevent, control or even treat diabetic neuropathy.

\subsection{Gut Microbiota in Cerebrovascular Disease}

Stroke is a major cause of disability worldwide and diabetes is one of many factors that increase stroke risk [87]. Additionally, poor blood sugar management negatively influences progression of cerebrovascular disease and increases mortality [88]. In most cases, it is difficult to determine with certainty what caused a stroke; however, recently research showed a link between gut microbiota dysbiosis and stroke incidence [89]. This may be due to the ability of the gut microbiota to interact with the central nervous system through endocrine, neuronal and immune pathways, directly affecting brain chemistry [90].

The composition of the gut microbiota changes in both rodents and humans after the onset of acute ischemic stroke. In a preclinical study using a rodent stroke model, increased amounts of Akkermensia municiphila and Clostridia spp. were noted in the experimental group post-stroke compared to the control animals [91]. Similarly, in human stroke patients, an increase of Lactobacillus ruminis and a decrease in Lactobacillus sakei was observed compared to the control group. [92,93]. Additionally, the gut microbiota of stroke 
patients included several species that produce short-chain fatty acids, such as Odoribacter, Akkermensia, Ruminococcaceae UCG-005 and Victivallis [93]. Dysbiosis of the gut microbiota that develops post-stroke leads to impairment of neuroinflammatory processes that affect stroke progression.

Symptomatic atherosclerosis has been associated with dysbiosis of the gut microbiota as well, supporting a potential link between the gut microbiota, cardiovascular and cerebrovascular diseases [94]. One study that investigated a group at risk of developing a stroke in China showed changes in gut microbiota composition such that there was an increase in the amount of opportunistic pathogenic bacteria, including Enterobacteriaceae and Veillonellaceae, as well as lactate-producing bacteria including Bifidobacterium and Lactobacillus. Furthermore, there was a reduction in butyrate-producing bacteria, including Lachnospiraceae and Ruminococcaceae, in people at high stroke risk compared to low-risk individuals. Based on these data, it is possible that dysbiosis of the gut microbiota alone may represent a stroke risk factor [95].

Trimethylamine-N-oxide (TMAO) is a commonly studied metabolite when considering the link between the gut microbiota and stroke risk. This metabolite is the result of the transformation of phosphatidylcholine and l-carnitine into trimethylamine, which is then absorbed and oxidized by hepatic flavin monooxygenase to form TMAO [96]. While some studies have shown an association between TMAO, atherosclerosis and the risk of stroke, the mechanisms by which this association occurs are not well understood. There is a significant correlation between TMAO levels and the amount of pro-inflammatory intermediate monocytes observed; therefore TMAO is believed to influence inflammation by promoting the growth of proinflammatory monocytes [97]. Other proposed mechanisms for the formation of TMAO associated with stroke or cerebrovascular accident include the promotion of platelet hyperreactivity [98], irregular cholesterol metabolism [99] and promotion of foam cell formation [100]. TMAO is also associated with other ischemic stroke risk factors such as arterial fibrillation [101] and diabetes [102].

Several studies have shown an association between gut microbiota dysbiosis and atherosclerosis in patients on a phosphatidylcholine-rich diet [100]. Increased TMAO levels were also associated with an increased risk of cardiovascular disease [100]. A study of Chinese patients with high blood pressure showed that increased TMAO levels were associated with increased stroke risk as well [103]. Jia Yin et al. observed that the level of TMAO in patients with a history of stroke or transient ischemic attack (TIA) was significantly lower than in the control group of asymptomatic individuals. Furthermore, patients with stroke and TIA also had a different gut microbiota composition than those in the control group. The gut microbiota of patients that had suffered from a stroke or TIA was characterized by an increase in the amount of harmful pathogenic bacteria Enterobacter, Megasphaera, Oscillibacter and Desulfovibrio, and a decrease in the amount of beneficial or commensal bacteria, such as Bacteroides, Prevotella and Faecalibacterium. Moreover, this study emphasized the association between dysbiosis of the gut microbiota and the severity of cerebrovascular disease [104]. Based on these data, evaluating the gut microbiota could be an invaluable metric when assessing stroke risk in patients.

Preclinical studies investigating the use of probiotic supplementation to improve gut dysbiosis associated with cerebrovascular disease show promising results. In mice, administration of a $10^{7} \mathrm{CFU} / \mathrm{mL}$ mixture of Bifidobacterium breve, Lactobacillus casei, Lactobacillus bulgaricus and Lactobacillus acidophilus 14 days prior to an ischemic event significantly reduced the size of the stroke by $52 \%$. Furthermore, this administration of probiotics led to a significant decrease in the content of malondialdehyde and TNF- $\alpha$ in the ischemic tissue of the brain. Despite the observed reduction of stroke size, the administered probiotics did not improve the neurological function of the experimental group mice compared to the control group [105]. While the preclinical data are promising, further clinical research is needed to investigate the effect of probiotic supplementation on human gut dysbiosis and associated cerebrovascular disease. 


\subsection{Gut Microbiota in Coronary Heart Disease}

Coronary artery disease is the leading cause of morbidity and mortality worldwide, as well as an important determinant of long-term prognosis in patients with diabetes. Diabetic patients with heart disease have a two-to-four times higher risk of mortality [106]. It is known that the gut microbiota plays a critical role in essential metabolic processes, such as cholesterol and uric acid metabolism in addition to influencing processes such as oxidative stress and inflammatory reactions through metabolites, which can lead to atherosclerosis or coronary heart disease [107]. Because hypercholesterolemia is a known risk factor for coronary artery disease, and dysbiosis of the gut microbiota can affect cholesterol metabolism, it follows that dysbiosis of the gut microbiota can be a risk factor for coronary artery disease [108]. Gut microbiota dysbiosis also affects the development of hypercholesterolemia by influencing the metabolism of cholesterol in the liver and by altering bile acids, which in turn affect circulating cholesterol levels [109]. Recently, a growing number of both preclinical and clinical studies have implicated gut microbiota in the occurrence of coronary heart disease. For example, patients with coronary artery disease showed increases in Collinsella bacteria [94], mature lactobacilli [110], EscherichiaShigella [111], Enterococcus [111] and the ratio of Firmicutes to Bacteroides [112]. Conversely, significant decreases in Roseburia and Eubacterium spp. [94], Bacteroides (Bifidobacterium and Prevotella) [110] and butyrate-carrying bacteria, such as Faecalibacterium, Roseburia and Eubacterium rectalae were observed in the gut microbiota of patients with coronary artery disease compared to healthy individuals [111].

In mice, antibiotic-induced changes in the gut microbiota significantly altered host metabolism and determined the severity of subsequent myocardial infarction [113]. On the other hand, addition of Lactobacillus plantarum and Lactobacillus rhamnosus reduced the size of the infraction, ameliorated left ventricular hypertrophy and improved left ventricular function post- infarction [114]. In humans, dysbiosis of the gut microbiota can lead to coronary artery disease, hypertension and heart failure [100]. For example, one study showed a higher frequency of coronary artery disease in the presence of a low proportion of intestinal bacteria [115]. It has been suggested that the gut microbiota influences the development of coronary artery disease by producing metabolites such as bile acids, coprostanol, short-chain fatty acids and TMAO. TMAO levels are strongly associated with coronary artery disease risk. Uric acid serum levels could also be an independent risk factor for coronary artery disease. Furthermore, elevated uric acid levels in patients with coronary artery disease are linked to dysfunction of the gut microbiota [116]. Patients with coronary artery disease showed a reduction in primary plasma bile acids and an increased ratio of secondary to primary bile acids in patients with heart failure [117], which could affect disease progression.

Studies investigating the effects of probiotic supplementation on the gut microbiota, diabetes and coronary artery disease have shown promising results. In patients with coronary artery disease, probiotics reduced blood lipids, thus reducing the risk of coronary artery disease [118]. Additionally, a group of 20 men with coronary artery disease who received a probiotic drink containing Lactobacillus plantarum 299 for six weeks showed improvement of endothelial vascular function and decreased systemic inflammation [119]. Another study monitored the effects of taking a probiotic supplement containing Bifidobacterium bifidum $2 \times 10^{9}$, Lactobacillus casei $2 \times 10^{9}$, Lactobacillus acidophilus $2 \times 10^{9} \mathrm{CFU} /$ day in patients with diabetes and coronary heart disease. After 12 weeks of this protocol, patients exhibited improved glycemic control, increased HDL-cholesterol, low total cholesterol to HDL-cholesterol ratio and a reduction in oxidative stress biomarkers [120]. In short, the use of probiotics is a promising approach to treatment of individuals with diabetes-associated gut dysbiosis and coronary artery disease.

\subsection{Gut Microbiota in Peripheral Vascular Disease}

Peripheral arterial disease (PAD) is a severe complication of late-stage type 2 diabetes. PAD is often associated with critical limb ischemia and gangrene. Diabetic foot is one 
example of this that often occurs with poorly controlled diabetes. This is characterized by hyperglycemia, hyperinsulinemia and dyslipidemia [121] and can result in increased systemic inflammation and oxidative stress as well as diabetic foot ulceration [122]. More than $25 \%$ of patients with diabetes are at risk of developing diabetic foot and associated ischemia, neuropathy or infection $[123,124]$. Lesions such as ulcers that develop in diabetic patients experience difficulty healing due to decreased blood flow caused by the accumulation of lipid plaques on the walls of the vessels. This delay in healing can cause inflammation and gangrene [125]. In addition, poor perception of pain caused by associated diabetic neuropathy often leads to delays in identifying and diagnosing diabetic peripheral vascular disease [126] and high limb amputation rate [127]. Despite wide prevalence and the severity of its consequences, peripheral vascular disease is the least studied vascular complication of diabetes [128].

The effects of probiotic supplementation on peripheral vascular disease and lesion healing have been investigated in preclinical rodent models. When kefir was administered to rats, it improved lesion healing due to the lactic acid producing bacteria that inhibits proliferation of pathogenic microbes. Other components of kefir, such as polysaccharides improved wound healing by stimulating the innate immune response against pathogens present in the wound [129]. The effects of probiotic supplementation on diabetic wound healing associated with peripheral vascular disease have also been investigated in humans. Diabetic foot patients who received a probiotic protocol for 12 weeks showed a reduction in the length, width and thickness of the diabetic foot ulcer. Furthermore, the probiotic supplement administered, consisting of Lactobacillus acidophilus, Lactobacillus casei, Lactobacillus fermentum and Bifidobacterium bifidum $\left(2 \times 10^{9} \mathrm{CFU} / \mathrm{g}\right.$ each), led to improvements in plasma glucose, serum insulin and the QUICKI indicator [130]. While not thoroughly investigated, it has been suggested that the mechanism by which probiotics improve diabetic foot ulcers is similar to the one involved in improving lesions in other areas of the body, by modulating the local immune response [131]. Thus, increasing the diversity and richness of the gut microbiota, and establish eubiosis through probiotic supplementation may provide some benefits to patients with complications of diabetic peripheral vascular disease by improving glycemic control, insulin, lipid metabolism and incretins [132] (Table 2 and Figure 1). For example, in a proof-of-concept, randomized double-blind controlled clinical trial study, Depommier et al. showed that supplementation for three months with A. muciniphila significantly improved insulin sensitivity, reduced insulinemia, plasma total cholesterol and inflammation [133]. These results show that intervention with specific bacteria strains may prove a useful strategy in improving metabolic parameters associated with diabetes and its complications. Indeed, several bacteria with enhanced functional characteristics in treating specific host diseases have been defined as next generation probiotics (NGP). Among them, Akkermansia muciniphila, Ruminococcus bromii, Faecalibacterium prausnitzii, Anaerobutyricum hallii and Roseburia intestinalis have gained considerable interest and have been the primary candidates. In particular, A. muciniphila have been associated with improved metabolic endotoxemia, amelioration of metabolic syndrome phenotype, improved lipid and glucose metabolism and may serve as diagnostic tool for dietary interventions. Likewise, Faecalibacterium prausnitzii has been shown to exert anti-inflammatory action and has been proposed as a biomarker for the development of gut diseases and for assessing dietary interventions in intestinal inflammatory conditions [134] (Table 2). Based on these findings, several novel food and pharma supplements have been developed with profound beneficial effects in protecting from specific metabolic disorders and other metabolic risks. 
Table 2. Effects of probiotic or synbiotic on glycemia, insulin, lipid metabolism and incretins.

\begin{tabular}{|c|c|c|c|c|c|c|c|c|c|c|c|}
\hline Reference & Year & Location & Design & $\begin{array}{l}\text { Participants, } \\
\text { Age, Nr. } \\
\text { Treated/ Nr. } \\
\text { Controls }\end{array}$ & $\begin{array}{l}\text { Probiotic } \\
\text { Source }\end{array}$ & Probiotic Dose, CFU & $\begin{array}{l}\text { Study } \\
\text { Period } \\
(w k / d)\end{array}$ & Glycemia & Insulin & $\begin{array}{c}\text { Lipid } \\
\text { Metabolism }\end{array}$ & Incretins \\
\hline [135] & 2002 & Poland & $\mathrm{RD}, \mathrm{DB}, \mathrm{CT}$ & $\begin{array}{c}\text { Healthy } \\
\text { participants } \\
35-45 \mathrm{y} \\
18 / 18\end{array}$ & $\begin{array}{l}\text { rose-hip } \\
\text { drink }\end{array}$ & $\begin{array}{l}\text { L. plantarum } 299 v \text {, } \\
5 \times 10^{7} \mathrm{CFU} / \mathrm{mL}\end{array}$ & $6 \mathrm{wk}$ & $=F G$ & $=\mathrm{I}$ & $\begin{array}{c}\text { =TC, LDL-C, } \\
\text { HDL-C, TG, } \\
\text { lipopro- } \\
\text { tein(a) }\end{array}$ & S $\downarrow$ leptin \\
\hline [136] & 2006 & Australia & $\begin{array}{c}\text { DB, PC, } \\
\text { parallel } \\
\text { design trial, } \\
\text { single centre }\end{array}$ & $\begin{array}{c}\text { Healthy } \\
\text { volunteers } \\
30-75 \text { y } \\
23 / 21\end{array}$ & capsule & $\begin{array}{l}\text { L. fermentum, } \\
2 \times 10^{9} \mathrm{CFU}\end{array}$ & $10 \mathrm{wk}$ & $=F G$ & - & $\begin{array}{l}=\mathrm{LDL}-\mathrm{C}, \mathrm{TC}, \\
\text { HDL-C, TGL }\end{array}$ & - \\
\hline [137] & 2009 & Finland & $\begin{array}{c}\mathrm{RD}, \\
\text { prospective, } \\
\text { parallel- } \\
\text { group }\end{array}$ & $\begin{array}{c}\text { Pregnant women } \\
29.7 / 30.1 / 30.2 \text { y } \\
85 / 86 / 85\end{array}$ & capsule & $\begin{array}{l}\text { L. rhamnosus GG, } \\
\text { ATCC } 53 \text { 103, } \\
\text { B. lactis Bb12, } \\
10^{10} \text { CFU/d each }\end{array}$ & $4 \mathrm{wk}$ & $\begin{aligned} & S \downarrow F G, \\
= & \mathrm{HbA} 1 \mathrm{c}\end{aligned}$ & $\begin{array}{c}\mathrm{S} \downarrow \mathrm{I}, \mathrm{HOMA}, \\
\mathrm{S} \uparrow \mathrm{QUICKI}\end{array}$ & - & - \\
\hline [138] & 2010 & Denmark & $\mathrm{RD}, \mathrm{PC}, \mathrm{DB}$ & $\begin{array}{l}\text { T2DM/non- } \\
\text { diabetic } \\
48-66 \text { y } \\
24 / 24\end{array}$ & capsule & $\begin{array}{l}\text { L. acidophilus NCFM, } \\
1 \mathrm{~g} \text {; about } 10^{10} \mathrm{CFU}\end{array}$ & $4 \mathrm{wk}$ & - & $=\mathrm{QUICKI}$ & - & - \\
\hline [139] & 2012 & Iran & $\mathrm{DB}, \mathrm{RD}, \mathrm{CT}$ & $\begin{array}{c}\text { T2DM } \\
30-60 y \\
32 / 32\end{array}$ & yogurt & $\begin{array}{c}\text { L. acidophilus La5, } \\
7.23 \times 10^{6}-1.85 \times 10^{6} \\
\mathrm{CFU} / \mathrm{g} \\
\text { B. lactis Bb12, } \\
6.04 \times 10^{6} \\
\mathrm{CFU} / \mathrm{g}-1.79 \times 10^{6} \\
\mathrm{CFU} / \mathrm{g}\end{array}$ & $6 \mathrm{wk}$ & $\begin{array}{l}\mathrm{S} \downarrow \mathrm{FG}, \\
\mathrm{HbA} 1 \mathrm{c}\end{array}$ & $=\mathrm{I}$ & - & - \\
\hline [140] & 2012 & Brazil & $\mathrm{DB}, \mathrm{PC}, \mathrm{RD}$ & $\begin{array}{c}\text { Healthy } \\
\text { participants } \\
50-65 \text { y } \\
10 / 10\end{array}$ & shake & $\begin{array}{c}\text { L. acidophillus, } \\
4 \times 10^{8} \mathrm{CFU} / 100 \mathrm{~mL} \\
\text { B. bifidum } \\
4 \times 10^{8} \mathrm{CFU} / 100 \mathrm{~mL} \\
1 \mathrm{~g} / 100 \mathrm{~mL} \text { FOS }\end{array}$ & $30 \mathrm{~d}$ & $\mathrm{~S} \downarrow \mathrm{FG}$ & - & $\begin{array}{l}\mathrm{S} \uparrow \mathrm{HDL}-\mathrm{C} \\
=\mathrm{TC}, \mathrm{TG}\end{array}$ & - \\
\hline
\end{tabular}


Table 2. Cont.

\begin{tabular}{|c|c|c|c|c|c|c|c|c|c|c|c|}
\hline Reference & Year & Location & Design & $\begin{array}{c}\text { Participants, } \\
\text { Age, Nr. } \\
\text { Treated/ Nr. } \\
\text { Controls }\end{array}$ & $\begin{array}{l}\text { Probiotic } \\
\text { Source }\end{array}$ & Probiotic Dose, CFU & $\begin{array}{l}\text { Study } \\
\text { Period } \\
(w k / d)\end{array}$ & Glycemia & Insulin & $\begin{array}{c}\text { Lipid } \\
\text { Metabolism }\end{array}$ & Incretins \\
\hline [141] & 2012 & Canada & $\begin{array}{c}\text { DB, PC, } \\
\text { multi-center } \\
\text { study }\end{array}$ & $\begin{array}{c}\text { Healthy } \\
\text { hypercholester- } \\
\text { olemic human } \\
\text { subjects } \\
20-75 \text { y } \\
67 / 64\end{array}$ & capsule & $\begin{array}{c}\text { L. reuteri NCIMB } \\
30242, \\
2.9 \times 10^{9} \mathrm{CFU}\end{array}$ & 9 wk & $=\mathrm{FG}$ & - & - & - \\
\hline [142] & 2012 & Denmark & $\mathrm{DB}, \mathrm{PC}, \mathrm{RD}$ & $\begin{array}{c}\text { Ob adolescents } \\
12-15 y \\
27 / 23\end{array}$ & capsule & $\begin{array}{c}\text { L. salivarius Ls-33 } \\
\text { ATCC SD5208, } \\
10^{10} \mathrm{CFU}\end{array}$ & $12 \mathrm{wk}$ & $=\mathrm{FG}$ & $\begin{array}{c}=\mathrm{I}, \\
\text { HOMA-IR }\end{array}$ & $\begin{array}{c}=\mathrm{TC}, \mathrm{HDL}-\mathrm{C}, \\
\text { LDL-C, TG }\end{array}$ & - \\
\hline [143] & 2013 & Iran & $\begin{array}{l}\text { RD, DB, PC, } \\
\text { CT }\end{array}$ & $\begin{array}{c}\text { T2DM } \\
35-70 y \\
27 / 27\end{array}$ & capsule & $\begin{array}{c}\text { L. acidophilus, } \\
2 \times 10^{9} \mathrm{CFU} \\
\text { L. casei, } \\
7 \times 10^{9} \mathrm{CFU} \\
\text { L. rhamnosus, } \\
1.5 \times 10^{9} \mathrm{CFU} \\
\text { L. bulgaricus, } \\
2 \times 10^{8} \mathrm{CFU} \\
\text { B. breve, } \\
2 \times 10^{10} \mathrm{CFU} \\
\text { B. longum, } \\
7 \times 10^{9} \mathrm{CFU} \\
\text { S. thermophiles, } \\
1.5 \times 10^{9} \mathrm{CFU} \\
100 \mathrm{mg} \text { FOS }\end{array}$ & $8 \mathrm{wk}$ & $\mathrm{S} \downarrow \mathrm{FG}$ & $\begin{array}{c}\text { S } \uparrow \mathrm{I} \\
\text { HOMA-IR }\end{array}$ & $\mathrm{S} \uparrow \mathrm{LDL}-\mathrm{C}$ & - \\
\hline
\end{tabular}


Table 2. Cont.

\begin{tabular}{|c|c|c|c|c|c|c|c|c|c|c|c|}
\hline Reference & Year & Location & Design & $\begin{array}{c}\text { Participants, } \\
\text { Age, Nr. } \\
\text { Treated/ Nr. } \\
\text { Controls }\end{array}$ & $\begin{array}{l}\text { Probiotic } \\
\text { Source }\end{array}$ & Probiotic Dose, CFU & $\begin{array}{l}\text { Study } \\
\text { Period } \\
(w k / d)\end{array}$ & Glycemia & Insulin & $\begin{array}{c}\text { Lipid } \\
\text { Metabolism }\end{array}$ & Incretins \\
\hline [144] & 2013 & Iran & $\mathrm{RD}, \mathrm{DB}, \mathrm{CT}$ & $\begin{array}{l}\text { Patients with } \\
\text { NASH } \\
18-75 \text { y } \\
34 / 36\end{array}$ & tablet & $\begin{array}{c}\text { L. acidophilus, } \\
1 \times 10^{8} \mathrm{CFU} \\
\text { L. casei, } \\
5 \times 10^{8} \mathrm{CFU} \\
\text { L. rhamnosus, } \\
7.5 \times 10^{7} \mathrm{CFU} \\
\text { L. bulgaricus, } \\
1.5 \times 10^{8} \mathrm{CFU} \\
\text { B. breve, } \\
5 \times 10^{7} \mathrm{CFU} \\
\text { B. longum, } \\
2.5 \times 10^{7} \mathrm{CFU} \\
\text { S. thermophilus, } \\
5 \times 10^{7} \mathrm{CFU} \\
350 \mathrm{mg} \text { FOS }\end{array}$ & $24 \mathrm{wk}$ & $S \downarrow F G$ & - & $\mathrm{S} \downarrow \mathrm{TC}, \mathrm{TG}$ & - \\
\hline [146] & 2013 & $\begin{array}{l}\text { Russian } \\
\text { Federation }\end{array}$ & $\begin{array}{c}\text { RD, DB, PC, } \\
\text { parallel pilot } \\
\text { study }\end{array}$ & $\begin{array}{c}\text { Patients with } \\
\text { metabolic } \\
\text { syndrome } \\
30-69 \text { y } \\
25 / 15\end{array}$ & cheese & $\begin{array}{l}\text { L. plantarum TENSIA, } \\
1.5 \times 10^{11} \mathrm{CFU} / \mathrm{g}\end{array}$ & 3 wk & $=\mathrm{FG}$ & - & $\begin{array}{l}=\mathrm{TC}, \mathrm{LDL}-\mathrm{C}, \\
\text { HDL-C, TG }\end{array}$ & - \\
\hline [147] & 2013 & Iran & $\mathrm{RD}, \mathrm{SB}, \mathrm{CT}$ & $\begin{array}{c}\text { Pregnant women } \\
37 / 33 \\
18-30 y\end{array}$ & yogurt & $\begin{array}{c}\text { L. acidophilus LA5, } \\
\text { B. animalis BB12, } \\
1 \times 10^{7} \mathrm{CFU}\end{array}$ & 9 wk & $=\mathrm{FG}$ & $\mathrm{S} \downarrow \mathrm{I}, \mathrm{HOMA}$ & - & - \\
\hline [148] & 2014 & Iran & $\begin{array}{l}\mathrm{RD}, \mathrm{DB}, \\
\text { cross-over } \\
\mathrm{CT}\end{array}$ & $\begin{array}{c}\text { T2DM } \\
35-70 y \\
62 / 62\end{array}$ & package & $\begin{array}{l}\text { L. sporogenes, } \\
27 \times 10^{7} \mathrm{CFU} \\
1.08 \mathrm{~g} \text { inulin }\end{array}$ & $6 \mathrm{wk}$ & $=\mathrm{FG}$ & $\begin{array}{c}\mathrm{S} \downarrow \mathrm{I} \\
=\mathrm{HOMA}-\mathrm{IR}\end{array}$ & $\begin{array}{l}=\mathrm{CT}, \mathrm{LDL}-\mathrm{C}, \\
\text { TG, HDL-C }\end{array}$ & - \\
\hline
\end{tabular}


Table 2. Cont.

\begin{tabular}{|c|c|c|c|c|c|c|c|c|c|c|c|}
\hline Reference & Year & Location & Design & $\begin{array}{c}\text { Participants, } \\
\text { Age, Nr. } \\
\text { Treated/ Nr. } \\
\text { Controls }\end{array}$ & $\begin{array}{l}\text { Probiotic } \\
\text { Source }\end{array}$ & Probiotic Dose, CFU & $\begin{array}{l}\text { Study } \\
\text { Period } \\
(w k / d)\end{array}$ & Glycemia & Insulin & $\begin{array}{c}\text { Lipid } \\
\text { Metabolism }\end{array}$ & Incretins \\
\hline [149] & 2014 & Iran & $\mathrm{RD}, \mathrm{DB}, \mathrm{CT}$ & $\begin{array}{c}\text { T2DM ov /ob } \\
\text { obese } \\
53.00 \pm 5.9 / \\
49.00 \pm 7.08 \mathrm{y} \\
22 / 22\end{array}$ & yogurt & $\begin{array}{c}\text { B. lactis Bb12, } \\
\text { L. acidophilus strain } \\
\text { La5, } \\
3.7 \times 10^{6} \mathrm{CFU} / \mathrm{g}\end{array}$ & $8 \mathrm{wk}$ & $\begin{array}{l}\mathrm{S} \downarrow \mathrm{HbA} 1 \mathrm{c} \\
\quad=\mathrm{FG}\end{array}$ & - & - & - \\
\hline [150] & 2014 & Ireland & $\mathrm{PC}, \mathrm{DB}, \mathrm{RD}$ & $\begin{array}{c}\text { Ob pregnant } \\
\text { women, } \\
31.4 \pm 5.0 / 31.0 \\
\pm 5.2 \mathrm{y} \\
63 / 75\end{array}$ & capsule & $\begin{array}{c}\text { L. salivarius UCC118, } \\
10^{9} \text { CFU }\end{array}$ & $4 \mathrm{wk}$ & $=\mathrm{FG}$ & $\begin{array}{c}=\mathrm{I}, \\
\text { HOMA-IR }\end{array}$ & $\begin{array}{l}=\text { TC, HDL-C, } \\
\text { LDL-C, TG }\end{array}$ & - \\
\hline [151] & 2014 & Australia & $\begin{array}{l}\text { RD, DB, } \\
\text { parallel } \\
\text { study }\end{array}$ & $\begin{array}{c}\text { Ov } \\
>55 y \\
40 / 37 / 39 / 40\end{array}$ & $\begin{array}{l}\text { Yogurt/ } \\
\text { capsule }\end{array}$ & $\begin{array}{l}\text { L. acidophilus La5, } \\
\text { B. lactis Bb12, } \\
3 \times 10^{9} \mathrm{CFU} / \mathrm{d}\end{array}$ & $6 \mathrm{wk}$ & $\begin{aligned} & \mathrm{S} \uparrow \mathrm{FG} \\
= & \mathrm{HbA} 1 \mathrm{c}\end{aligned}$ & $\begin{array}{c}\mathrm{S} \uparrow \\
\text { HOMA-IR } \\
=\mathrm{I}\end{array}$ & - & - \\
\hline [153] & 2014 & Japan & $\begin{array}{c}\text { SB, PC, } \\
\text { within- } \\
\text { subject, } \\
\text { repeated- } \\
\text { measure } \\
\text { intervention } \\
\text { trial }\end{array}$ & $\begin{array}{l}\text { Adults with } \\
\text { hypertriacyl- } \\
\text { glycerolemia, } \\
51.1 \pm 6.6 \mathrm{y} \\
10 / 10\end{array}$ & $\begin{array}{l}\text { fermented } \\
\text { mil }\end{array}$ & $\begin{array}{c}\text { L. gasseri SBT2055 } \\
(\mathrm{LG} 2055), \\
5 \times 10^{10} \mathrm{CFU} / 100 \mathrm{~g}\end{array}$ & $4 \mathrm{wk}$ & $\begin{array}{c}\mathrm{S} \uparrow \begin{array}{l}\mathrm{HbA} 1 \mathrm{c} \\
=\mathrm{FG}\end{array}\end{array}$ & $=\mathrm{I}$ & $\begin{array}{c}\text { S } \downarrow \text { NEFA } \\
=\text { TG, Apo } \\
\text { B-48, TC, } \\
\text { LDL-C, } \\
\text { HDL-C }\end{array}$ & - \\
\hline
\end{tabular}


Table 2. Cont.

\begin{tabular}{|c|c|c|c|c|c|c|c|c|c|c|c|}
\hline Reference & Year & Location & Design & $\begin{array}{c}\text { Participants, } \\
\text { Age, Nr. } \\
\text { Treated/ Nr. } \\
\text { Controls }\end{array}$ & $\begin{array}{c}\text { Probiotic } \\
\text { Source }\end{array}$ & Probiotic Dose, CFU & $\begin{array}{l}\text { Study } \\
\text { Period } \\
(w k / d)\end{array}$ & Glycemia & Insulin & $\begin{array}{c}\text { Lipid } \\
\text { Metabolism }\end{array}$ & Incretins \\
\hline [154] & 2014 & Iran & $\begin{array}{c}\mathrm{RD}, \mathrm{DB}, \mathrm{PC}, \\
\mathrm{CT}\end{array}$ & $\begin{array}{c}\text { NAFLD } \\
>18 y \\
26 / 26\end{array}$ & capsule & $\begin{array}{c}\text { L. casei, } \\
\text { L. rhamnosus, } \\
\text { S. thermophilus, } \\
\text { B. breve, } \\
\text { L. acidophilus, } \\
\text { B. longum, } \\
\text { L. bulgaricus } \\
2 \times 10^{8} \text { CFU } \\
250 \mathrm{mg} \text { FOS }\end{array}$ & $28 w k$ & $\mathrm{~S} \downarrow \mathrm{FG}$ & $\begin{array}{c}S \downarrow I, \\
\text { HOMA-IR }\end{array}$ & - & - \\
\hline [155] & 2014 & Iran & $\begin{array}{l}\text { RD, DB, PC } \\
\text { pilot study }\end{array}$ & $\begin{array}{c}\text { Patients with MS } \\
>18 \text { y } \\
19 / 19\end{array}$ & capsule & $\begin{array}{c}\text { L. casei, } \\
\text { L. rhamnosus, } \\
\text { S. thermophilus, } \\
\text { B. breve, } \\
\text { L. acidophilus, } \\
\text { B. longum, } \\
\text { L. bulgaricus } \\
2 \times 10^{8} \text { CFU } \\
250 \mathrm{mg} \text { FOS }\end{array}$ & $28 w k$ & $\mathrm{~S} \downarrow \mathrm{FG}$ & $\begin{array}{c}\mathrm{S} \downarrow \mathrm{I}, \\
\text { HOMA-IR } \\
\text { S } \uparrow \text { QUICKI }\end{array}$ & $\begin{array}{c}=\mathrm{LDL}-\mathrm{C} \\
\mathrm{S} \downarrow \mathrm{TG}, \mathrm{CT} \\
\mathrm{S} \uparrow \mathrm{HDL}\end{array}$ & - \\
\hline [156] & 2014 & Iran & $\mathrm{RD}, \mathrm{PC}, \mathrm{CT}$ & $\begin{array}{c}\text { Pregnant women } \\
18-35 \text { y } \\
26 / 26\end{array}$ & food & $\begin{array}{l}\text { L. sporogenes, } \\
1 \times 10^{7} \text { CFU } \\
0.04 \mathrm{~g} \text { inulin }\end{array}$ & $9 \mathrm{wk}$ & $=\mathrm{FG}$ & $\begin{array}{c}\text { S } \downarrow \text { I, } \\
\text { HOMA-IR, } \\
\text { HOMA-B } \\
\text { S } \uparrow \text { QUICKI }\end{array}$ & - & - \\
\hline [157] & 2014 & Iran & $\mathrm{RD}, \mathrm{DB}, \mathrm{CT}$ & $\begin{array}{c}\text { T2DM } \\
35-70 y \\
26 / 26 / 26\end{array}$ & bread & $\begin{array}{l}\text { L. sporogenes, } \\
1 \times 10^{8} \mathrm{CFU} \\
0.07 \mathrm{~g} \text { inulin }\end{array}$ & $8 w k$ & $=\mathrm{FG}$ & - & $\begin{array}{c}\text { S } \downarrow \text { TG, } \\
\text { VLDL-C, } \\
\text { TC } / \text { HDL-C } \\
\text { S } \uparrow \text { HDL-C } \\
=\text { TC, LDL-C, } \\
\text { HDL-C }\end{array}$ & - \\
\hline
\end{tabular}


Table 2. Cont.

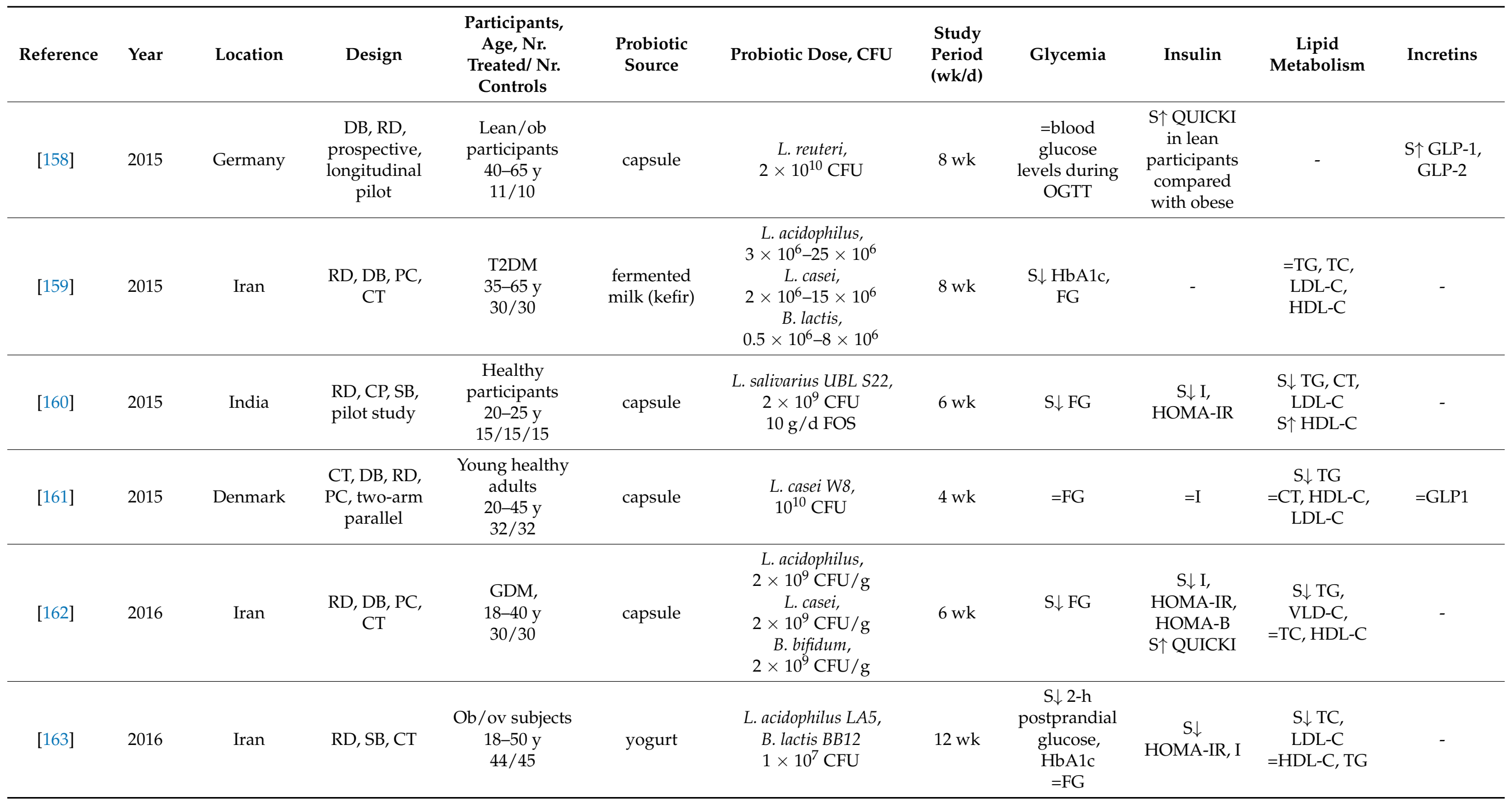


Table 2. Cont.

\begin{tabular}{|c|c|c|c|c|c|c|c|c|c|c|c|}
\hline Reference & Year & Location & Design & $\begin{array}{l}\text { Participants, } \\
\text { Age, Nr. } \\
\text { Treated/ Nr. } \\
\text { Controls }\end{array}$ & $\begin{array}{l}\text { Probiotic } \\
\text { Source }\end{array}$ & Probiotic Dose, CFU & $\begin{array}{l}\text { Study } \\
\text { Period } \\
\text { (wk/d) }\end{array}$ & Glycemia & Insulin & $\begin{array}{c}\text { Lipid } \\
\text { Metabolism }\end{array}$ & Incretins \\
\hline [164] & 2016 & Estonia & $\begin{array}{l}\text { preliminary, } \\
\text { open label } \\
\text { study }\end{array}$ & $\begin{array}{l}\text { Clinically } \\
\text { healthy } \\
\text { volunteers } \\
50-75 \text { y }\end{array}$ & capsule & $\begin{array}{c}\text { L. fermentum ME-3 } \\
(\text { LFME-3), } \\
6 \times 10^{9} \mathrm{CFU}\end{array}$ & $4 \mathrm{wk}$ & $\mathrm{S} \downarrow \mathrm{HbA} 1 \mathrm{c}$ & $\begin{array}{c}S \downarrow \\
\text { HOMA-IR }\end{array}$ & $\begin{array}{c}\mathrm{S} \downarrow \text { LDL-C, } \\
\text { oxLDL, TC, } \\
\text { TG, } \\
\text { TG/HDL-C } \\
\text { ratio } \\
\mathrm{S} \uparrow \text { HDL-C }\end{array}$ & - \\
\hline [165] & 2017 & Sweden & RD, PC & $\begin{array}{c}\text { T2DM } \\
50-75 y \\
15 / 15 / 16\end{array}$ & stick pack & $\begin{array}{l}\text { L. reuteri DSM 17938, } \\
10^{8} \text { CFU / day } \\
\text { L. reuteri DSM 17938, } \\
10^{10} \text { CFU/day }\end{array}$ & $12 \mathrm{wk}$ & $\begin{aligned} &=\mathrm{FG} \\
&=\mathrm{HbA} 1 \mathrm{c}\end{aligned}$ & $\mathrm{S} \uparrow \mathrm{QUICKI}$ & $\begin{array}{l}=\mathrm{CT}, \mathrm{HDL}, \\
\text { LDL, TGL }\end{array}$ & - \\
\hline [17] & 2017 & Iran & $\mathrm{RD}, \mathrm{CT}$ & $\begin{array}{c}\text { T2DM, ov, } \\
\text { CHD patients } \\
40-85 \text { y } \\
30 / 30\end{array}$ & capsule & $\begin{array}{l}\text { L. acidophilus, } \\
2 \times 10^{9} \\
\text { L. casei, } \\
2 \times 10^{9} \\
\text { B. bifidum, } \\
2 \times 10^{9} \mathrm{CFU} / \mathrm{g} \\
800 \mathrm{mg} \text { inulin }\end{array}$ & $12 \mathrm{wk}$ & $\mathrm{S} \downarrow \mathrm{FG}$ & $\begin{array}{c}\mathrm{S} \downarrow \mathrm{I}, \\
\text { HOMA-B } \\
\mathrm{S} \uparrow \text { QUICKI } \\
=\text { HOMA-IR }\end{array}$ & $\begin{array}{c}\mathrm{S} \uparrow \text { HDL-C } \\
=\mathrm{TG}, \mathrm{TC}, \\
\text { LDL-C, } \\
\text { VLDL-C, } \\
\text { TC/HDL-C } \\
\text { ratio }\end{array}$ & - \\
\hline [166] & 2017 & Malaysia & $\begin{array}{l}\mathrm{RD}, \mathrm{DB}, \\
\text { parallel- } \\
\text { group, } \\
\mathrm{CT}\end{array}$ & $\begin{array}{c}\text { T2DM, } \\
30-70 y \\
68 / 68\end{array}$ & sachet & $\begin{array}{c}\text { L. acidophilus, } \\
\text { L. casei, } \\
\text { L. lactis, } \\
\text { B. bifidum, } \\
\text { B. longum, } \\
\text { B. infantis, } \\
10^{10} \mathrm{CFU} / \mathrm{d} \text { each }\end{array}$ & $12 \mathrm{wk}$ & $\begin{array}{c}\mathrm{S} \downarrow \mathrm{HbA} 1 \mathrm{c} \\
=\mathrm{FG}\end{array}$ & $\begin{array}{c}\mathrm{S} \downarrow \mathrm{I} \\
=\mathrm{HOMA}-\mathrm{IR}, \\
\text { QUICKI }\end{array}$ & $\begin{array}{l}=\mathrm{TC}, \mathrm{TG}, \\
\text { LDL-C, } \\
\text { HDL-C }\end{array}$ & - \\
\hline [167] & 2017 & Brazil & $\begin{array}{c}\mathrm{DB}, \mathrm{RD}, \mathrm{PC}, \\
\mathrm{CT}\end{array}$ & $\begin{array}{c}\text { T2DM } \\
35-60 y \\
25 / 25\end{array}$ & $\begin{array}{l}\text { fermented } \\
\text { goat milk }\end{array}$ & $\begin{array}{l}\text { L. acidophilus La-5, } \\
\text { B. lactis BB-12, } \\
10^{9} \mathrm{CFU} / \mathrm{d} \text { each }\end{array}$ & $6 \mathrm{wk}$ & $\begin{array}{c}\mathrm{S} \downarrow \text { FS } \\
=\mathrm{HbA} 1 \mathrm{c}, \mathrm{FG}\end{array}$ & $\begin{array}{c}=\mathrm{I} \\
\text { HOMA-IR }\end{array}$ & $\begin{array}{c}\text { S } \downarrow \text { TC, } \\
\text { LDL-C } \\
=\text { HDL, } \\
\text { VLDL, TG. } \\
\text { CT /HLD-C } \\
\text { ratio }\end{array}$ & - \\
\hline
\end{tabular}


Table 2. Cont.

\begin{tabular}{|c|c|c|c|c|c|c|c|c|c|c|c|}
\hline Reference & Year & Location & Design & $\begin{array}{c}\text { Participants, } \\
\text { Age, Nr. } \\
\text { Treated/ Nr. } \\
\text { Controls }\end{array}$ & $\begin{array}{l}\text { Probiotic } \\
\text { Source }\end{array}$ & Probiotic Dose, CFU & $\begin{array}{l}\text { Study } \\
\text { Period } \\
(w k / d)\end{array}$ & Glycemia & Insulin & $\begin{array}{c}\text { Lipid } \\
\text { Metabolism }\end{array}$ & Incretins \\
\hline [9] & 2017 & Saudi Arabia & $\mathrm{DB}, \mathrm{RD}, \mathrm{CT}$ & $\begin{array}{c}\text { T2DM } \\
30-60 y \\
48 / 46\end{array}$ & sachet & $\begin{array}{c}\text { B. bifidum W23, } \\
\text { B. lactis W52, } \\
\text { L. acidophilus W37, } \\
\text { L. brevis W63, } \\
\text { L. casei W56, } \\
\text { L. salivarius W24, } \\
\text { Lactococcus lactis W19, } \\
\text { Lactococcus lactis W58, } \\
2.5 \times 10^{9} \text { CFU } / g\end{array}$ & $12 \mathrm{wk}$ & $=\mathrm{FG}$ & $\begin{array}{c}S \downarrow \\
\text { HOMA-IR } \\
=\mathrm{I}\end{array}$ & $\begin{array}{c}=\mathrm{TG}, \mathrm{TC}, \\
\text { HDL-C, } \\
\text { LDL-C, } \\
\text { TC } / \mathrm{HDL} \\
\text { ratio }\end{array}$ & - \\
\hline [168] & 2017 & Iran & $\begin{array}{c}\mathrm{RD}, \mathrm{DB}, \mathrm{PC}, \\
\mathrm{CT}\end{array}$ & $\begin{array}{l}\text { NAFLD patients } \\
\text { with normal or } \\
\text { low BMI } \\
>18 \mathrm{y} \\
25 / 25\end{array}$ & capsule & $\begin{array}{c}\text { L. casei, } \\
\text { L. rhamnosus, } \\
\text { S. thermophilus, } \\
\text { B. breve, } \\
\text { L. acidophilus, } \\
\text { B. longum, } \\
\text { L. bulgaricus } \\
2 \times 10^{8} \text { CFU }\end{array}$ & $28 w k$ & $\mathrm{~S} \downarrow \mathrm{FG}$ & $\begin{array}{c}=\text { HOMA-IR, } \\
\text { I, QUICKI }\end{array}$ & $\begin{array}{c}=\mathrm{LDL}-\mathrm{C}, \\
\text { HDL-C, TC } \\
\text { S } \downarrow \text { TG }\end{array}$ & - \\
\hline [169] & 2018 & Taiwan & $\mathrm{DB}, \mathrm{RD}, \mathrm{PC}$ & $\begin{array}{c}\text { T2DM } \\
25-70 y \\
25 / 25 / 24\end{array}$ & capsule & $\begin{array}{l}\text { ADR-1 (live L. reuteri), } \\
4 \times 10^{9} \mathrm{CFU} \\
\text { cells of ADR- } 3 \\
\text { (heat-killed L. reuteri), } \\
\quad 2 \times 10^{10} \mathrm{CFU}\end{array}$ & $24 \mathrm{wk}$ & $\begin{array}{c}=\text { fasting } \\
\text { blood } \\
\text { glucose } \\
\text { S } \downarrow \text { HbA1c in } \\
\text { liver ADR-1 } \\
=\text { HbA1c in } \\
\text { heat-killed } \\
\text { ADR03, }\end{array}$ & $\begin{array}{c}=\mathrm{I}, \\
\text { HOMA-IR }\end{array}$ & $\begin{array}{c}=\text { LDL-C, free } \\
\text { fatty acids } \\
\text { S } \downarrow \text { TC in } \\
\text { ADR-1 }\end{array}$ & - \\
\hline [170] & 2018 & Iran & $\begin{array}{c}\mathrm{DB}, \mathrm{RD}, \mathrm{PC}, \\
\text { parallel- } \\
\text { group, } \\
\mathrm{CT}\end{array}$ & $\begin{array}{c}\text { Prediabetes } \\
40 / 40 / 40 \\
35-75 \text { y }\end{array}$ & powder & $\begin{array}{c}\text { L. acidophilus, } \\
\text { B. lactis, } \\
\text { B. bifidum, } \\
\text { B. longum } \\
1 \times 10^{9} \text { CFU } / \text { each } \\
\text { inulin }\end{array}$ & $24 \mathrm{wk}$ & $\begin{array}{l}\mathrm{S} \downarrow \mathrm{FG}, \\
\mathrm{HbA} 1 \mathrm{c}\end{array}$ & $\begin{array}{c}\quad \mathrm{S} \downarrow \mathrm{I}, \\
\text { HOMA-IR } \\
\mathrm{S} \uparrow \text { QUICKI } \\
=\text { HOMA-B }\end{array}$ & - & - \\
\hline
\end{tabular}


Table 2. Cont.

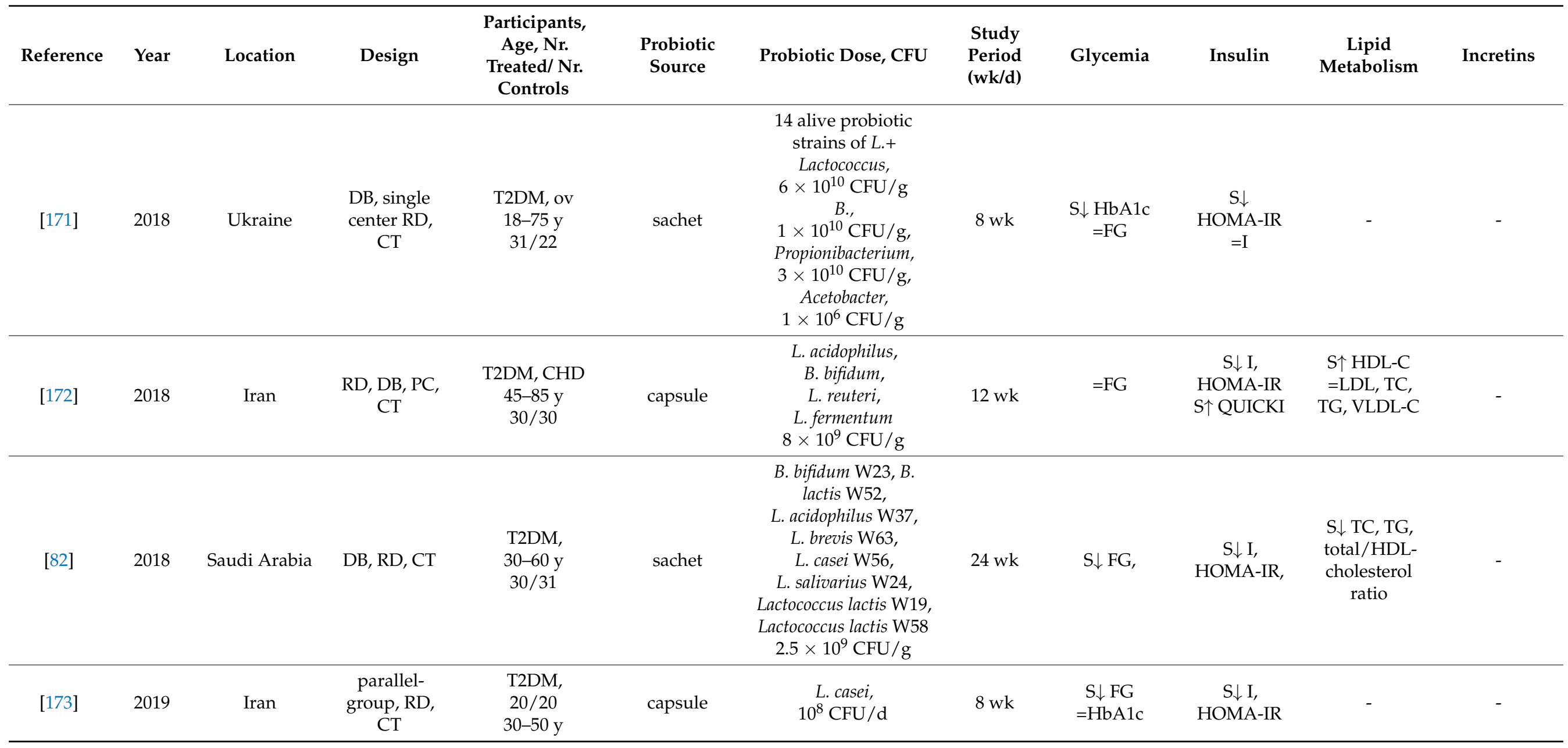


Table 2. Cont.

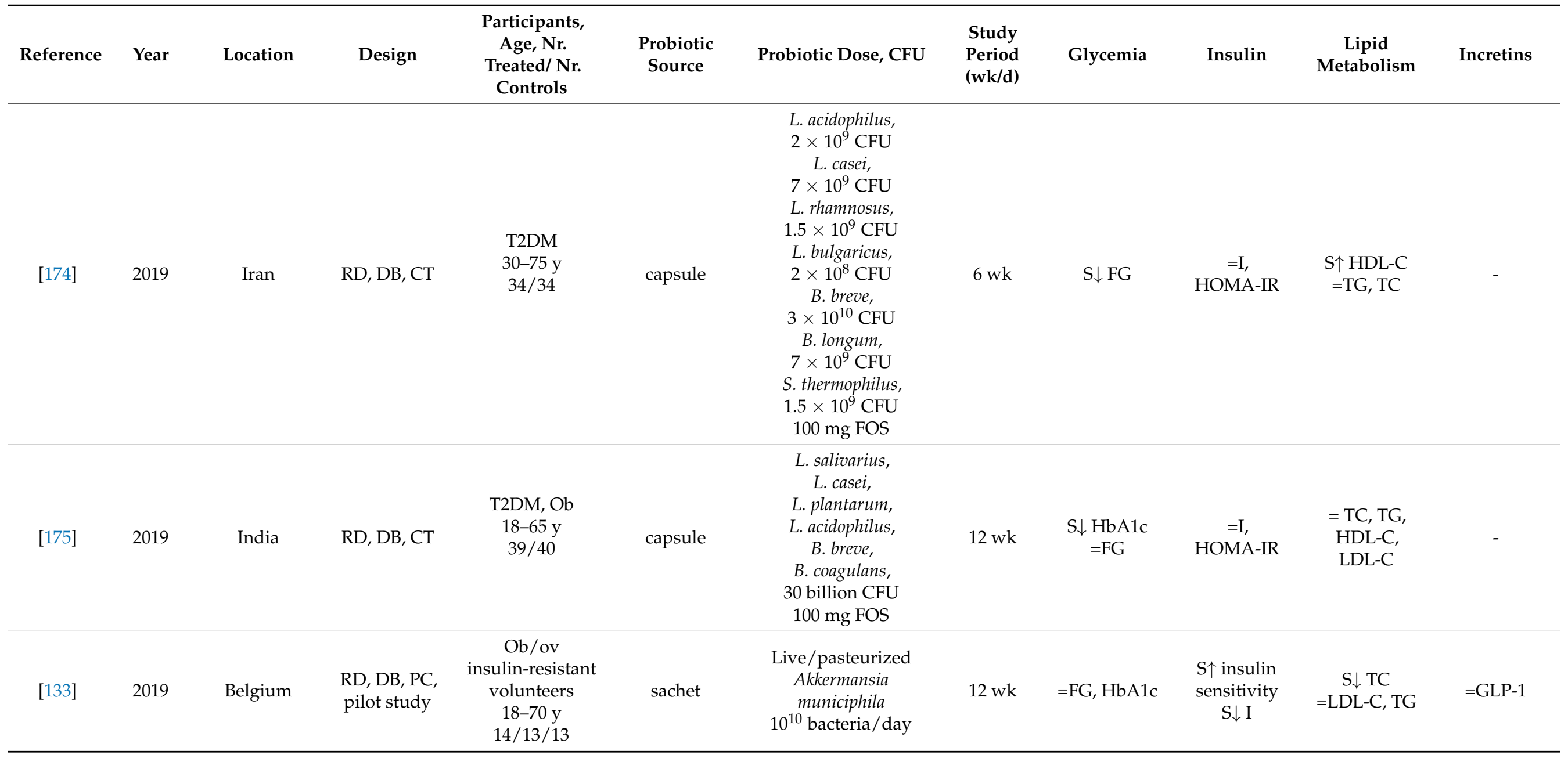


Table 2. Cont.

\begin{tabular}{|c|c|c|c|c|c|c|c|c|c|c|c|}
\hline Reference & Year & Location & Design & $\begin{array}{c}\text { Participants, } \\
\text { Age, Nr. } \\
\text { Treated/ Nr. } \\
\text { Controls }\end{array}$ & $\begin{array}{c}\text { Probiotic } \\
\text { Source }\end{array}$ & Probiotic Dose, CFU & $\begin{array}{l}\text { Study } \\
\text { Period } \\
(w k / d)\end{array}$ & Glycemia & Insulin & $\begin{array}{c}\text { Lipid } \\
\text { Metabolism }\end{array}$ & Incretins \\
\hline [176] & 2020 & Australia & $\mathrm{RD}, \mathrm{DB}, \mathrm{CT}$ & $\begin{array}{c}\text { T2DM } \\
\text { BMI } \geq 25 \mathrm{~kg} / \mathrm{m}^{2} \\
\geq 18 \mathrm{y} \\
30 / 30\end{array}$ & capsule & $\begin{array}{c}\text { L. plantarum, } \\
6 \times 10^{9} \mathrm{CFU}, \\
\text { L. bulgaricus, } \\
3 \times 10^{9} \mathrm{CFU} \\
\text { L. gasseri, } \\
18 \times 10^{9} \mathrm{CFU} \\
\text { B. breve, } \\
7.5 \times 10^{9} \mathrm{CFU} \\
\text { B. animalis sbsp. } \\
\text { lactis, } \\
8 \times 10^{9} \mathrm{CFU} \\
\text { B. bifidum, } \\
7 \times 10^{9} \mathrm{CFU} \\
\text { S. thermophiles, } \\
450 \times 10^{6} \mathrm{CFU} \\
\text { Saccharomyces boulardii, } \\
45 \times 10^{6} \mathrm{CFU}\end{array}$ & $12 \mathrm{wk}$ & $\begin{array}{c}\mathrm{S} \downarrow \mathrm{FG}, \\
\text { HbA1c } \\
\text { (in patients } \\
\text { taking } \\
\text { probiotics } \\
\text { and } \\
\text { metformin) }\end{array}$ & $\begin{array}{c}\mathrm{S} \downarrow \\
\text { HOMA-IR } \\
\text { (in patients } \\
\text { taking } \\
\text { probiotics } \\
\text { and } \\
\text { metformin) }\end{array}$ & - & - \\
\hline
\end{tabular}

RD, randomized; DB, double-blind; PC, placebo-controlled; SB, single-blind; CT, clinical trial; T2DM, type 2 diabetes mellitus; Ob, obese; NASH, Nonalcoholic steatohepatitis; Ov Overweight; NAFLD, Non-alcoholic fatty liver disease; MS, Metabolic syndrome; GDM, gestational diabetes mellitus; CHD, coronary heart disease; L., Lactobacillus; B., Bifidobacterium; S., Streptococcus; CFU, colony-forming units; FOS, fructooligosaccharides; wk, weeks; d, days; FG, fasting glucose fasting blood glucose, fasting plasma glucose, glycemia, fasting blood sugar; HbA1c, Hemoglobin glycated; OGTT, glucose tolerance test; I, serum insulin concentration, insulin concentration, serum insulin level, insulin; HOMA, homeostatic model assessment; HOMA-IR, homeostasis model of assessment-estimated insulin resistance; QUICKI, quantitative insulin sensitivity check index; HOMA-B, homeostasis model assssessment of $\beta$-cell dysfunction; TG, triglycerides; VLDL, very-low-density lipoprotein; TC, total cholesterol; HDL-C, high-density lipoprotein; LDL-C, low-density lipoprotein; NEFA non-esterified fatty acids; Apo B-48, apolipoprotein B-48; oxLDL, oxidatively modified low density lipoprotein; GLP-1, Glucagon-like peptide-1; GLP-2, Glucagon-like peptide-2; =, non significan; S, significant; $\uparrow$, increase; $\downarrow$, decrease. 
PROBIOTICS, PREBIOTICS, SYNBIOTICS, FECAL MICROBIOTA TRANSPLANTATION
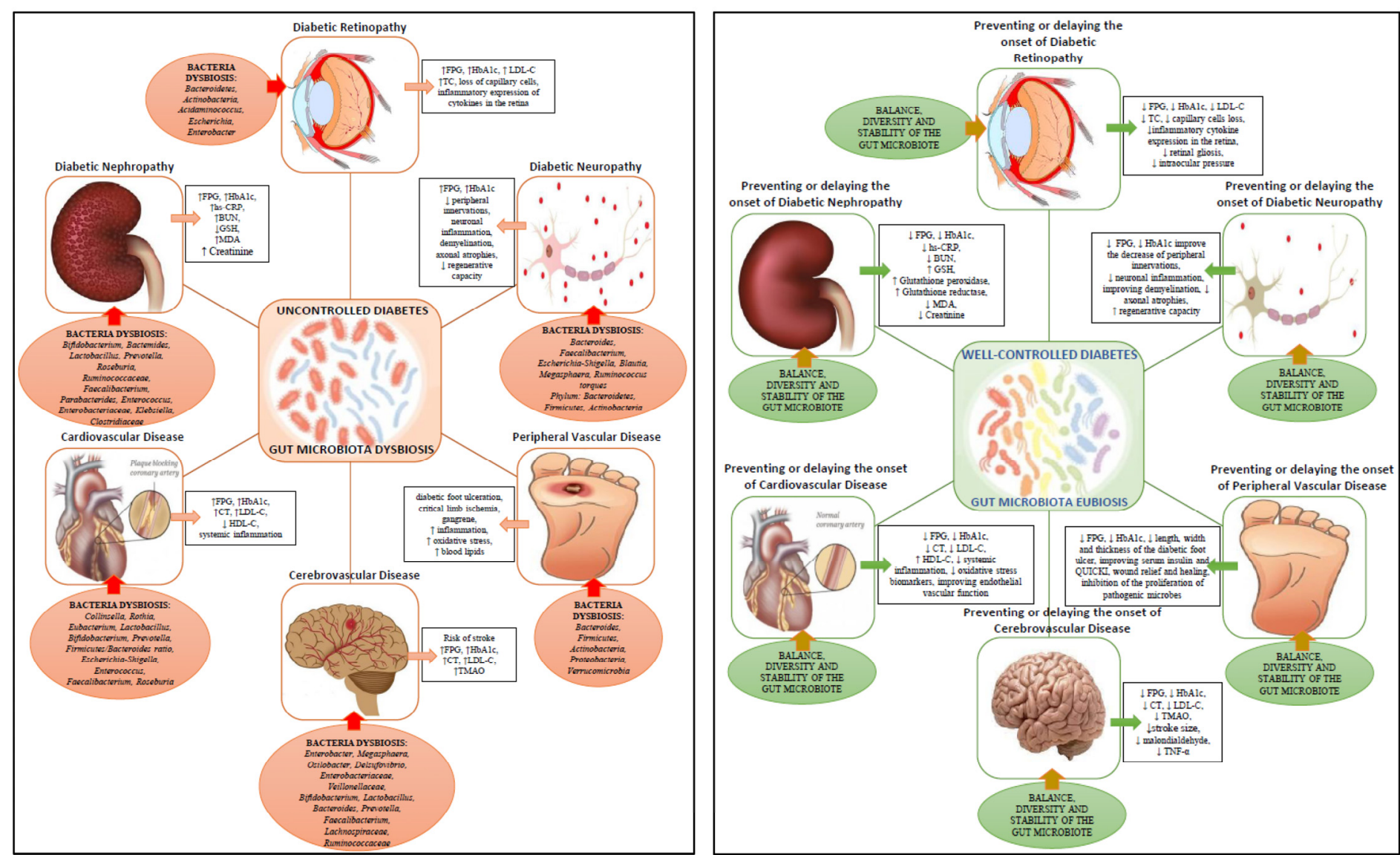

Figure 1. Schematic view of the link between gut microbiota, diabetes and chronic complications of diabetes. The left side panel depicts chronic micro- and macrovascular complications of diabetes, and associated changes in the composition of the gut microbiota. Poorly controlled diabetes leads to chronic complications over time, and dysbiosis of the gut microbiota seems to promote the onset and progression of these complications. The right panel depicts the potential effects of restoring gut microbiota eubiosis in ameliorating, preventing or delaying the onset of chronic complications of diabetes, via probiotics, prebiotics, symbiotics or by fecal microbiota transplantation. $\uparrow$, increase; $\downarrow$, decrease. 


\section{Conclusions and Future Perspectives}

For the past decade or so, owing to rapid methodological advances in genome sequencing of microbes, an avalanche of studies has rushed to uncover the potential contribution of the so called "forgotten organ" (i.e., gut microbiota) in multiple pathologies, including metabolic disorders. While significant strides have been made toward understanding the complex interaction between bacteria and the host, particularly at the biochemical, cellular and molecular level, we are still in the early stages when it comes to our understanding of whether gut bacteria play a direct role in prevention, development and treatment of diseases. As it is the case with most pathologies in which the effects of gut microbiota have been studied, the development of diabetes and its complications have been linked with the state of dysbiosis of the gut microbiota. This, in and of itself, raises a wide range of questions, since "dysbiosis" is a loose term used to characterize a disequilibrium, in a given organism and time [177]. As noted throughout this review, it is well documented that diabetes and its complications are characterized by systemic inflammation, therefore it is not surprising that numerous studies focused on examining the anti-inflammatory effects of certain bacteria such as Roseburia in patients with coronary artery disease, Lachnospiraceae in patients at high stroke risk and Faecalibacterium in patients with diabetic nephropathy, diabetic neuropathy, cerebrovascular disease or coronary artery disease. As such, low abundance of anti-inflammatory bacteria, along with the increased abundance of proinflammatory bacteria has been attributed to the onset and progression of complications of diabetes. Similarly, bacterial metabolites such as SCFA and TMAO have been shown to influence host physiology and improve disease outcome. Notwithstanding such promising findings, we are still very much grasping with the demonstration, beyond doubt, of a causal relationship between gut bacteria and diabetes and its complications. Whereas preclinical studies are promising and show direct effect of some bacteria on certain metabolic and clinical parameters of diabetes, the results in humans are less promising, with few clinical trials and by and large, have been inconsistent. Thus, for the modulation of gut microbiota via prebiotics, probiotics, FMT or other means to be part of any therapeutic protocol in diabetes and its complications, its causal effect in these diseases must be defined and clinically demonstrated. Preclinical animal models such as germ free or antibiotic treated animals have been useful in examining host-microbiota interactions via controlling the effects of individual bacteria, through monocolonization or combined bacteria therapy, however, they each come with significant caveats that often preclude generalization of findings to human disease prevention and treatment. Considering that bacterial strains of the same species may differ in up to $30 \%$ of their genomic structure when compared by taxonomic analysis, it follows that gut microbiota must be viewed and analyzed as a system. Similarly, microbial metabolites associated with the gut microbiota, type 2 diabetes and associated complications that act synergistically must be analyzed and their effects tested [178]. It is equally important to examine the dynamical changes in the composition profile and production of metabolic byproducts of gut microbiota prior, during and after the onset of diabetes and its complications in order to determine dynamic changes during disease progression. While to date the list of bacteria reported to affect several parameters characteristic of diabetes complications is steadily increasing, very few have been studied as therapeutic approaches in these pathologies. Likewise, efforts should be dedicated toward identification of bacteria signatures and metabolites that will allow early detection of disease risks, and the mechanisms involved, making possible to personalize therapeutic intervention based on individual's needs, stage and particularities of the disease. Therefore, modulation of the gut microbiota through prebiotics, probiotics, synbiotics or fecal microbiota transfer may have beneficial effects in the management of diabetes and associated complications; however, further research involving human trials should be high on the list.

Author Contributions: All authors contributed to the conceptualization, writing and article preparation. All authors have read and agreed to the published version of the manuscript. 
Funding: This research was funded by the project "The analysis of interrelationship between gut microbiota and the host with applications in the prevention and control of type 2 diabetes" cofinanced by European Regional Development Fund through Competitiveness Operational Program under the contract number 120/16.09.2016.

Institutional Review Board Statement: Not applicable.

Informed Consent Statement: Not applicable.

Data Availability Statement: Not applicable.

Conflicts of Interest: The authors declare no conflict of interest.

\section{References}

1. D'Argenio, V.; Salvatore, F. The role of the gut microbiome in the healthy adult status. Clin. Chim. Acta 2015, 451, 97-102. [CrossRef] [PubMed]

2. Matijasic, M.; Mestrovic, T.; Paljetak, H.C.; Peric, M.; Baresic, A.; Verbanac, D. Gut Microbiota beyond Bacteria-Mycobiome, Virome, Archaeome, and Eukaryotic Parasites in IBD. Int. J. Mol. Sci. 2020, 21, 2668. [CrossRef]

3. Jayasudha, R.; Das, T.; Kalyana Chakravarthy, S.; Sai Prashanthi, G.; Bhargava, A.; Tyagi, M.; Rani, P.K.; Pappuru, R.R.; Shivaji, S. Gut mycobiomes are altered in people with type 2 Diabetes Mellitus and Diabetic Retinopathy. PLoS ONE 2020, 15 , e0243077. [CrossRef]

4. Mazloom, K.; Siddiqi, I.; Covasa, M. Probiotics: How Effective Are They in the Fight against Obesity? Nutrients 2019, 11, 258. [CrossRef]

5. Mar Rodriguez, M.; Perez, D.; Javier Chaves, F.; Esteve, E.; Marin-Garcia, P.; Xifra, G.; Vendrell, J.; Jove, M.; Pamplona, R.; Ricart, W.; et al. Obesity changes the human gut mycobiome. Sci. Rep. 2015, 5, 14600. [CrossRef] [PubMed]

6. Kowalewska, B.; Zorena, K.; Szmigiero-Kawko, M.; Waz, P.; Mysliwiec, M. Higher diversity in fungal species discriminates children with type 1 diabetes mellitus from healthy control. Patient Prefer. Adherence 2016, 10, 591-599. [CrossRef]

7. Pataky, Z.; Bobbioni-Harsch, E.; Hadengue, A.; Carpentier, A.; Golay, A. Gut microbiota, responsible for our body weight? Rev. Med. Suisse 2009, 5, 662-664.

8. Marchesi, J.R.; Adams, D.H.; Fava, F.; Hermes, G.D.; Hirschfield, G.M.; Hold, G.; Quraishi, M.N.; Kinross, J.; Smidt, H.; Tuohy, K.M.; et al. The gut microbiota and host health: A new clinical frontier. Gut 2016, 65, 330-339. [CrossRef] [PubMed]

9. Sabico, S.; Al-Mashharawi, A.; Al-Daghri, N.M.; Yakout, S.; Alnaami, A.M.; Alokail, M.S.; McTernan, P.G. Effects of a multi-strain probiotic supplement for 12 weeks in circulating endotoxin levels and cardiometabolic profiles of medication naive T2DM patients: A randomized clinical trial. J. Transl. Med. 2017, 15, 249. [CrossRef]

10. Khalili, L.; Alipour, B.; Asghari Jafarabadi, M.; Hassanalilou, T.; Mesgari Abbasi, M.; Faraji, I. Probiotic assisted weight management as a main factor for glycemic control in patients with type 2 diabetes: A randomized controlled trial. Diabetol. Metab. Syndr. 2019, 11, 5. [CrossRef] [PubMed]

11. Saeedi, P.; Petersohn, I.; Salpea, P.; Malanda, B.; Karuranga, S.; Unwin, N.; Colagiuri, S.; Guariguata, L.; Motala, A.A.; Ogurtsova, K.; et al. Global and regional diabetes prevalence estimates for 2019 and projections for 2030 and 2045: Results from the International Diabetes Federation Diabetes Atlas, 9(th) edition. Diabetes Res. Clin. Pract. 2019, 157, 107843. [CrossRef]

12. DeFronzo, R.A. Current issues in the treatment of type 2 diabetes. Overview of newer agents: Where treatment is going. Am. J. Med. 2010, 123, S38-S48. [CrossRef]

13. Bekyarova, G.Y.; Ivanova, D.G.; Madjova, V.H. Molecular mechanisms associating oxidative stress with endothelial dysfunction in the development of various vascular complications in diabetes mellitus. Folia Med. 2007, 49, 13-19.

14. Baig, M.A.; Panchal, S.S. Streptozotocin-Induced Diabetes Mellitus in Neonatal Rats: An Insight into its Applications to Induce Diabetic Complications. Curr. Diabetes Rev. 2019, 16, 26-39. [CrossRef] [PubMed]

15. Gourgari, E.; Dabelea, D.; Rother, K. Modifiable Risk Factors for Cardiovascular Disease in Children with Type 1 Diabetes: Can Early Intervention Prevent Future Cardiovascular Events? Curr. Diabetes Rep. 2017, 17, 134. [CrossRef] [PubMed]

16. Heianza, Y.; Sun, D.; Ma, W.; Zheng, Y.; Champagne, C.M.; Bray, G.A.; Sacks, F.M.; Qi, L. Gut-microbiome-related LCT genotype and 2-year changes in body composition and fat distribution: The POUNDS Lost Trial. Int. J. Obes. 2018, 42, 1565-1573. [CrossRef]

17. Tajabadi-Ebrahimi, M.; Sharifi, N.; Farrokhian, A.; Raygan, F.; Karamali, F.; Razzaghi, R.; Taheri, S.; Asemi, Z. A Randomized Controlled Clinical Trial Investigating the Effect of Synbiotic Administration on Markers of Insulin Metabolism and Lipid Profiles in Overweight Type 2 Diabetic Patients with Coronary Heart Disease. Exp. Clin. Endocrinol. Diabetes 2017, 125, 21-27. [CrossRef]

18. Wang, Y.; Branicky, R.; Noe, A.; Hekimi, S. Superoxide dismutases: Dual roles in controlling ROS damage and regulating ROS signaling. J. Cell Biol. 2018, 217, 1915-1928. [CrossRef]

19. Constantino, M.I.; Molyneaux, L.; Limacher-Gisler, F.; Al-Saeed, A.; Luo, C.; Wu, T.; Twigg, S.M.; Yue, D.K.; Wong, J. Long-term complications and mortality in young-onset diabetes: Type 2 diabetes is more hazardous and lethal than type 1 diabetes. Diabetes Care 2013, 36, 3863-3869. [CrossRef] [PubMed]

20. Lee, C.B.; Chae, S.U.; Jo, S.J.; Jerng, U.M.; Bae, S.K. The Relationship between the Gut Microbiome and Metformin as a Key for Treating Type 2 Diabetes Mellitus. Int. J. Mol. Sci. 2021, 22, 3566. [CrossRef] 
21. Mardinoglu, A.; Boren, J.; Smith, U. Confounding Effects of Metformin on the Human Gut Microbiome in Type 2 Diabetes. Cell Metab. 2016, 23, 10-12. [CrossRef] [PubMed]

22. Wu, H.; Esteve, E.; Tremaroli, V.; Khan, M.T.; Caesar, R.; Manneras-Holm, L.; Stahlman, M.; Olsson, L.M.; Serino, M.; Planas-Felix M.; et al. Metformin alters the gut microbiome of individuals with treatment-naive type 2 diabetes, contributing to the therapeutic effects of the drug. Nat. Med. 2017, 23, 850-858. [CrossRef] [PubMed]

23. Fernandes, R.; Viana, S.D.; Nunes, S.; Reis, F. Diabetic gut microbiota dysbiosis as an inflammaging and immunosenescence condition that fosters progression of retinopathy and nephropathy. Biochim. Biophys. Acta Mol. Basis. Dis. 2019, 1865, $1876-1897$. [CrossRef]

24. Chen, W.; Zhang, M.; Guo, Y.; Wang, Z.; Liu, Q.; Yan, R.; Wang, Y.; Wu, Q.; Yuan, K.; Sun, W. The Profile and Function of Gut Microbiota in Diabetic Nephropathy. Diabetes Metab. Syndr. Obes. 2021, 14, 4283-4296. [CrossRef]

25. Gross, J.L.; de Azevedo, M.J.; Silveiro, S.P.; Canani, L.H.; Caramori, M.L.; Zelmanovitz, T. Diabetic nephropathy: Diagnosis, prevention, and treatment. Diabetes Care 2005, 28, 164-176. [CrossRef] [PubMed]

26. Gupta, A.; Gupta, P.; Biyani, M. Targeted therapies in diabetic nephropathy: An update. J. Nephrol. 2011, 24, 686-695. [CrossRef] [PubMed]

27. Ritz, E. Nephropathy in type 2 diabetes. J. Intern. Med. 1999, 245, 111-126. [CrossRef] [PubMed]

28. Sabatino, A.; Regolisti, G.; Cosola, C.; Gesualdo, L.; Fiaccadori, E. Intestinal Microbiota in Type 2 Diabetes and Chronic Kidney Disease. Curr. Diabetes Rep. 2017, 17, 16. [CrossRef] [PubMed]

29. Jha, V.; Garcia-Garcia, G.; Iseki, K.; Li, Z.; Naicker, S.; Plattner, B.; Saran, R.; Wang, A.Y.; Yang, C.W. Chronic kidney disease: Global dimension and perspectives. Lancet 2013, 382, 260-272. [CrossRef]

30. Tuttle, K.R.; Bakris, G.L.; Bilous, R.W.; Chiang, J.L.; de Boer, I.H.; Goldstein-Fuchs, J.; Hirsch, I.B.; Kalantar-Zadeh, K.; Narva, A.S.; Navaneethan, S.D.; et al. Diabetic kidney disease: A report from an ADA Consensus Conference. Am. J. Kidney Dis. 2014, 64, 510-533. [CrossRef]

31. McMullan, C.J.; Lambers Heerspink, H.J.; Parving, H.H.; Dwyer, J.P.; Forman, J.P.; de Zeeuw, D. Visit-to-visit variability in blood pressure and kidney and cardiovascular outcomes in patients with type 2 diabetes and nephropathy: A post hoc analysis from the RENAAL study and the Irbesartan Diabetic Nephropathy Trial. Am. J. Kidney Dis. 2014, 64, 714-722. [CrossRef]

32. Navarro-Gonzalez, J.F.; Mora-Fernandez, C.; Muros de Fuentes, M.; Garcia-Perez, J. Inflammatory molecules and pathways in the pathogenesis of diabetic nephropathy. Nat. Rev. Nephrol. 2011, 7, 327-340. [CrossRef]

33. Singh, D.K.; Winocour, P.; Farrington, K. Oxidative stress in early diabetic nephropathy: Fueling the fire. Nat. Rev. Endocrinol. 2011, 7, 176-184. [CrossRef] [PubMed]

34. Ramezani, A.; Massy, Z.A.; Meijers, B.; Evenepoel, P.; Vanholder, R.; Raj, D.S. Role of the Gut Microbiome in Uremia: A Potential Therapeutic Target. Am. J. Kidney Dis. 2016, 67, 483-498. [CrossRef] [PubMed]

35. Mahmoodpoor, F.; Rahbar Saadat, Y.; Barzegari, A.; Ardalan, M.; Zununi Vahed, S. The impact of gut microbiota on kidney function and pathogenesis. Biomed. Pharm. 2017, 93, 412-419. [CrossRef] [PubMed]

36. Vaziri, N.D.; Yuan, J.; Nazertehrani, S.; Ni, Z.; Liu, S. Chronic kidney disease causes disruption of gastric and small intestinal epithelial tight junction. Am. J. Nephrol. 2013, 38, 99-103. [CrossRef] [PubMed]

37. Kieffer, D.A.; Piccolo, B.D.; Vaziri, N.D.; Liu, S.; Lau, W.L.; Khazaeli, M.; Nazertehrani, S.; Moore, M.E.; Marco, M.L.; Martin, R.J.; et al. Resistant starch alters gut microbiome and metabolomic profiles concurrent with amelioration of chronic kidney disease in rats. Am. J. Physiol.-Renal Physiol. 2016, 310, F857-F871. [CrossRef]

38. Fukuuchi, F. Intestinal bacteria-derived putrefactants in chronic renal failure. Clin. Exp. Nephrol. 2002, 6, 99-104. [CrossRef]

39. Xu, K.Y.; Xia, G.H.; Lu, J.Q.; Chen, M.X.; Zhen, X.; Wang, S.; You, C.; Nie, J.; Zhou, H.W.; Yin, J. Impaired renal function and dysbiosis of gut microbiota contribute to increased trimethylamine-N-oxide in chronic kidney disease patients. Sci. Rep. 2017, 7, 1445. [CrossRef]

40. Jiang, S.; Xie, S.; Lv, D.; Wang, P.; He, H.; Zhang, T.; Zhou, Y.; Lin, Q.; Zhou, H.; Jiang, J.; et al. Alteration of the gut microbiota in Chinese population with chronic kidney disease. Sci. Rep. 2017, 7, 2870. [CrossRef]

41. Kanbay, M.; Onal, E.M.; Afsar, B.; Dagel, T.; Yerlikaya, A.; Covic, A.; Vaziri, N.D. The crosstalk of gut microbiota and chronic kidney disease: Role of inflammation, proteinuria, hypertension, and diabetes mellitus. Int. Urol. Nephrol. 2018, 50, 1453-1466. [CrossRef]

42. Ranganathan, N.; Friedman, E.A.; Tam, P.; Rao, V.; Ranganathan, P.; Dheer, R. Probiotic dietary supplementation in patients with stage 3 and 4 chronic kidney disease: A 6-month pilot scale trial in Canada. Curr. Med. Res. Opin. 2009, 25, 1919-1930. [CrossRef]

43. Wang, F.; Jiang, H.; Shi, K.; Ren, Y.; Zhang, P.; Cheng, S. Gut bacterial translocation is associated with microinflammation in end-stage renal disease patients. Nephrology 2012, 17, 733-738. [CrossRef] [PubMed]

44. Takayama, F.; Taki, K.; Niwa, T. Bifidobacterium in gastro-resistant seamless capsule reduces serum levels of indoxyl sulfate in patients on hemodialysis. Am. J. Kidney Dis. 2003, 41, S142-S145. [CrossRef]

45. Cruz-Mora, J.; Martinez-Hernandez, N.E.; Martin del Campo-Lopez, F.; Viramontes-Horner, D.; Vizmanos-Lamotte, B.; MunozValle, J.F.; Garcia-Garcia, G.; Parra-Rojas, I.; Castro-Alarcon, N. Effects of a symbiotic on gut microbiota in Mexican patients with end-stage renal disease. J. Renal Nutr. 2014, 24, 330-335. [CrossRef]

46. Rossi, M.; Johnson, D.W.; Morrison, M.; Pascoe, E.M.; Coombes, J.S.; Forbes, J.M.; Szeto, C.C.; McWhinney, B.C.; Ungerer, J.P.; Campbell, K.L. Synbiotics Easing Renal Failure by Improving Gut Microbiology (SYNERGY): A Randomized Trial. Clin. J. Am. Soc. Nephrol. 2016, 11, 223-231. [CrossRef] [PubMed] 
47. Miranda Alatriste, P.V.; Urbina Arronte, R.; Gomez Espinosa, C.O.; Espinosa Cuevas Mde, L. Effect of probiotics on human blood urea levels in patients with chronic renal failure. Nutr. Hosp. 2014, 29, 582-590. [CrossRef]

48. Simenhoff, M.L.; Dunn, S.R.; Zollner, G.P.; Fitzpatrick, M.E.; Emery, S.M.; Sandine, W.E.; Ayres, J.W. Biomodulation of the toxic and nutritional effects of small bowel bacterial overgrowith in end-stage kidney disease using freeze-dried Lactobacillus acidophilus. Min. Electrolyte Metab. 1996, 22, 92-96.

49. Dunn, S.R.; Simenhoff, M.L.; Ahmed, K.E.; Gaughan, W.J.; Eltayeb, B.O.; Fitzpatrick, M.E.; Emery, S.M.; Ayres, J.W.; Holt, K.E. Effect of Oral Administration of Freeze-Dried Lactobacillus acidophilus on Small Bowel Bacterial Overgrowith in Patients with End Stage Kidney Disease: Reducing Uremic Toxins and Improving Nutrition. Int. Dairy J. 1998, 8, 545-553. [CrossRef]

50. Mafi, A.; Namazi, G.; Soleimani, A.; Bahmani, F.; Aghadavod, E.; Asemi, Z. Metabolic and genetic response to probiotics supplementation in patients with diabetic nephropathy: A randomized, double-blind, placebo-controlled trial. Food Funct. 2018, 9, 4763-4770. [CrossRef]

51. Abbasi, B.; Ghiasvand, R.; Mirlohi, M. Kidney Function Improvement by Soy Milk Containing Lactobacillus plantarum A7 in Type 2 Diabetic Patients with Nephropathy: A Double-Blinded Randomized Controlled Trial. Iran. J. Kidney Dis. 2017, 11, 36-43.

52. Soleimani, A.; Zarrati Mojarrad, M.; Bahmani, F.; Taghizadeh, M.; Ramezani, M.; Tajabadi-Ebrahimi, M.; Jafari, P.; Esmaillzadeh, A.; Asemi, Z. Probiotic supplementation in diabetic hemodialysis patients has beneficial metabolic effects. Kidney Int. 2017, 91, 435-442. [CrossRef]

53. Mazruei Arani, N.; Emam-Djomeh, Z.; Tavakolipour, H.; Sharafati-Chaleshtori, R.; Soleimani, A.; Asemi, Z. The Effects of Probiotic Honey Consumption on Metabolic Status in Patients with Diabetic Nephropathy: A Randomized, Double-Blind, Controlled Trial. Probiotics Antimicrob. Proteins 2019, 11, 1195-1201. [CrossRef]

54. Miraghajani, M.; Zaghian, N.; Dehkohneh, A.; Mirlohi, M.; Ghiasvand, R. Probiotic Soy Milk Consumption and Renal Function Among Type 2 Diabetic Patients with Nephropathy: A Randomized Controlled Clinical Trial. Probiotics Antimicrob. Proteins 2019, 11, 124-132. [CrossRef]

55. Miraghajani, M.; Zaghian, N.; Mirlohi, M.; Feizi, A.; Ghiasvand, R. The Impact of Probiotic Soy Milk Consumption on Oxidative Stress Among Type 2 Diabetic Kidney Disease Patients: A Randomized Controlled Clinical Trial. J. Renal Nutr. 2017, 27, 317-324. [CrossRef]

56. Papatheodorou, K.; Papanas, N.; Banach, M.; Papazoglou, D.; Edmonds, M. Complications of Diabetes 2016. J. Diabetes Res. 2016, 2016, 6989453. [CrossRef]

57. Lee, R.; Wong, T.Y.; Sabanayagam, C. Epidemiology of diabetic retinopathy, diabetic macular edema and related vision loss. Eye Vis. 2015, 2, 17. [CrossRef]

58. Beli, E.; Yan, Y.; Moldovan, L.; Vieira, C.P.; Gao, R.; Duan, Y.; Prasad, R.; Bhatwadekar, A.; White, F.A.; Townsend, S.D.; et al. Restructuring of the Gut Microbiome by Intermittent Fasting Prevents Retinopathy and Prolongs Survival in db/db Mice. Diabetes 2018, 67, 1867-1879. [CrossRef] [PubMed]

59. Bader, M. Tissue renin-angiotensin-aldosterone systems: Targets for pharmacological therapy. Annu. Rev. Pharm. Toxicol. 2010, 50, 439-465. [CrossRef] [PubMed]

60. Das, A. Diabetic Retinopathy: Battling the Global Epidemic. Investig. Ophthalmol. Vis. Sci. 2016, 57, 6669-6682. [CrossRef] [PubMed]

61. Dominguez, J.M., 2nd; Hu, P.; Caballero, S.; Moldovan, L.; Verma, A.; Oudit, G.Y.; Li, Q.; Grant, M.B. Adeno-Associated Virus Overexpression of Angiotensin-Converting Enzyme-2 Reverses Diabetic Retinopathy in Type 1 Diabetes in Mice. Am. J. Pathol. 2016, 186, 1688-1700. [CrossRef]

62. Jeganathan, V.S. The therapeutic implications of renin-angiotensin system blockade in diabetic retinopathy. Curr. Pharm. Biotechnol. 2011, 12, 392-395. [CrossRef] [PubMed]

63. Perkins, B.A.; Aiello, L.P.; Krolewski, A.S. Diabetes complications and the renin-angiotensin system. N. Engl. J. Med. 2009, 361, 83-85. [CrossRef]

64. Sjolie, A.K.; Dodson, P.; Hobbs, F.R. Does renin-angiotensin system blockade have a role in preventing diabetic retinopathy? A clinical review. Int. J. Clin. Pract. 2011, 65, 148-153. [CrossRef] [PubMed]

65. Verma, A.; Shan, Z.; Lei, B.; Yuan, L.; Liu, X.; Nakagawa, T.; Grant, M.B.; Lewin, A.S.; Hauswirth, W.W.; Raizada, M.K.; et al. ACE2 and Ang-(1-7) confer protection against development of diabetic retinopathy. Mol. Ther. 2012, 20, 28-36. [CrossRef] [PubMed]

66. Caspi, R.R. In this issue: Immunology of the eye-Inside and out. Int. Rev. Immunol. 2013, 32, 1-3. [CrossRef]

67. Tap, J.; Mondot, S.; Levenez, F.; Pelletier, E.; Caron, C.; Furet, J.P.; Ugarte, E.; Munoz-Tamayo, R.; Paslier, D.L.; Nalin, R.; et al. Towards the human intestinal microbiota phylogenetic core. Environ. Microbiol. 2009, 11, 2574-2584. [CrossRef]

68. Huang, Y.; Yang, B.; Li, W. Defining the normal core microbiome of conjunctival microbial communities. Clin. Microbiol. Infect. 2016, 22, 643.e7-643.e12. [CrossRef]

69. Ozkan, J.; Willcox, M.; Wemheuer, B.; Wilcsek, G.; Coroneo, M.; Thomas, T. Biogeography of the human ocular microbiota. Ocul. Surf. 2019, 17, 111-118. [CrossRef]

70. Lu, L.J.; Liu, J. Human Microbiota and Ophthalmic Disease. Yale J. Biol. Med. 2016, 89, 325-330.

71. Das, T.; Jayasudha, R.; Chakravarthy, S.; Prashanthi, G.S.; Bhargava, A.; Tyagi, M.; Rani, P.K.; Pappuru, R.R.; Sharma, S.; Shivaji, S. Alterations in the gut bacterial microbiome in people with type 2 diabetes mellitus and diabetic retinopathy. Sci. Rep. 2021, 11, 2738. [CrossRef] [PubMed] 
72. Liu, W.; Wang, C.; Xia, Y.; Xia, W.; Liu, G.; Ren, C.; Gu, Y.; Li, X.; Lu, P. Elevated plasma trimethylamine-N-oxide levels are associated with diabetic retinopathy. Acta Diabetol. 2021, 58, 221-229. [CrossRef] [PubMed]

73. Huang, Y.; Wang, Z.; Ma, H.; Ji, S.; Chen, Z.; Cui, Z.; Chen, J.; Tang, S. Dysbiosis and Implication of the Gut Microbiota in Diabetic Retinopathy. Front. Cell Infect. Microbiol. 2021, 11, 646348. [CrossRef] [PubMed]

74. Verma, A.; Xu, K.; Du, T.; Zhu, P.; Liang, Z.; Liao, S.; Zhang, J.; Raizada, M.K.; Grant, M.B.; Li, Q. Expression of Human ACE2 in Lactobacillus and Beneficial Effects in Diabetic Retinopathy in Mice. Mol. Methods Clin. Dev. 2019, 14, 161-170. [CrossRef]

75. LI, Q.; XU, K.; DU, T.; ZHU, P.; VERMA, A. Recombinant Probiotics Expressing Angiotensin-(1-7) Improves Glucose Metabolism and Diabetes-Induced Renal and Retinal Injury. Diabetes 2018, 67, 33-LB. [CrossRef]

76. Petit Homme, R.; George, A.K.; Stanisic, D.N.; Malonee, C.; Molnar, J.; Smolenkova, I.; Sandhu, H.A.S.; Tyagi, S.C.; Singh, M. Effects of Probiotic on the Development of Diabetic Retinopathy. Investig. Ophthalmol. Vis. Sci. 2020,61, 4961.

77. Vinik, A.I.; Nevoret, M.L.; Casellini, C.; Parson, H. Diabetic neuropathy. Endocrinol. Metab. Clin. Neurol. Am. 2013, 42, 747-787. [CrossRef]

78. Grasset, E.; Burcelin, R. The gut microbiota to the brain axis in the metabolic control. Rev. Endocr. Metab. Disord. 2019, 20, 427-438. [CrossRef]

79. Yagihashi, S.; Mizukami, H.; Sugimoto, K. Mechanism of diabetic neuropathy: Where are we now and where to go? J. Diabetes Investig. 2011, 2, 18-32. [CrossRef]

80. Rolim, L.C.; da Silva, E.M.; Flumignan, R.L.; Abreu, M.M.; Dib, S.A. Acetyl-L-carnitine for the treatment of diabetic peripheral neuropathy. Cochrane Database Syst. Rev. 2019, 6, CD011265. [CrossRef]

81. Wang, Y.; Ye, X.; Ding, D.; Lu, Y. Characteristics of the intestinal flora in patients with peripheral neuropathy associated with type 2 diabetes. J. Int. Med. Res. 2020, 48, 300060520936806. [CrossRef] [PubMed]

82. Sabico, S.; Al-Mashharawi, A.; Al-Daghri, N.M.; Wani, K.; Amer, O.E.; Hussain, D.S.; Ahmed Ansari, M.G.; Masoud, M.S.; Alokail, M.S.; McTernan, P.G. Effects of a 6-month multi-strain probiotics supplementation in endotoxemic, inflammatory and cardiometabolic status of T2DM patients: A randomized, double-blind, placebo-controlled trial. Clin. Nutr. 2019, 38, 1561-1569. [CrossRef] [PubMed]

83. Lin, B.; Wang, Y.; Zhang, P.; Yuan, Y.; Zhang, Y.; Chen, G. Gut microbiota regulates neuropathic pain: Potential mechanisms and therapeutic strategy. J. Headache Pain 2020, 21, 103. [CrossRef]

84. Defaye, M.; Gervason, S.; Altier, C.; Berthon, J.Y.; Ardid, D.; Filaire, E.; Carvalho, F.A. Microbiota: A novel regulator of pain. J. Neural. Transm. 2020, 127, 445-465. [CrossRef] [PubMed]

85. Yang, N.J.; Chiu, I.M. Bacterial Signaling to the Nervous System through Toxins and Metabolites. J. Mol. Biol. 2017, 429, 587-605. [CrossRef] [PubMed]

86. Blake, K.J.; Baral, P.; Voisin, T.; Lubkin, A.; Pinho-Ribeiro, F.A.; Adams, K.L.; Roberson, D.P.; Ma, Y.C.; Otto, M.; Woolf, C.J.; et al. Staphylococcus aureus produces pain through pore-forming toxins and neuronal TRPV1 that is silenced by QX-314. Nat. Commun. 2018, 9, 37. [CrossRef]

87. Feigin, V.L.; Forouzanfar, M.H.; Krishnamurthi, R.; Mensah, G.A.; Connor, M.; Bennett, D.A.; Moran, A.E.; Sacco, R.L.; Anderson, L.; Truelsen, T.; et al. Global and regional burden of stroke during 1990-2010: Findings from the Global Burden of Disease Study 2010. Lancet 2014, 383, 245-254. [CrossRef]

88. Stevens, R.J.; Coleman, R.L.; Adler, A.I.; Stratton, I.M.; Matthews, D.R.; Holman, R.R. Risk Factors for Myocardial Infarction Case Fatality and Stroke Case Fatality in Type 2 Diabetes. UKPDS 2004, 27, 201-207. [CrossRef]

89. Clemente, J.C.; Ursell, L.K.; Parfrey, L.W.; Knight, R. The impact of the gut microbiota on human health: An integrative view. Cell 2012, 148, 1258-1270. [CrossRef]

90. Carabotti, M.; Scirocco, A.; Maselli, M.A.; Severi, C. The gut-brain axis: Interactions between enteric microbiota, central and enteric nervous systems. Ann. Gastroenterol. 2015, 28, 203-209.

91. Stanley, D.; Moore, R.J.; Wong, C.H.Y. An insight into intestinal mucosal microbiota disruption after stroke. Sci. Rep. 2018, 8, 568 [CrossRef] [PubMed]

92. Yamashiro, K.; Tanaka, R.; Urabe, T.; Ueno, Y.; Yamashiro, Y.; Nomoto, K.; Takahashi, T.; Tsuji, H.; Asahara, T.; Hattori, N. Gut dysbiosis is associated with metabolism and systemic inflammation in patients with ischemic stroke. PLOS ONE 2017, 12, e0171521. [CrossRef]

93. Li, N.; Wang, X.; Sun, C.; Wu, X.; Lu, M.; Si, Y.; Ye, X.; Wang, T.; Yu, X.; Zhao, X.; et al. Change of intestinal microbiota in cerebral ischemic stroke patients. BMC Microbiol. 2019, 19, 191. [CrossRef]

94. Karlsson, F.H.; Fak, F.; Nookaew, I.; Tremaroli, V.; Fagerberg, B.; Petranovic, D.; Backhed, F.; Nielsen, J. Symptomatic atherosclerosis is associated with an altered gut metagenome. Nat. Commun. 2012, 3, 1245. [CrossRef]

95. Zeng, X.; Gao, X.; Peng, Y.; Wu, Q.; Zhu, J.; Tan, C.; Xia, G.; You, C.; Xu, R.; Pan, S.; et al. Higher Risk of Stroke Is Correlated with Increased Opportunistic Pathogen Load and Reduced Levels of Butyrate-Producing Bacteria in the Gut. Front. Cell. Infect. Microbiol. 2019, 9, 4. [CrossRef] [PubMed]

96. Tang, W.H.W.; Wang, Z.; Levison, B.S.; Koeth, R.A.; Britt, E.B.; Fu, X.; Wu, Y.; Hazen, S.L. Intestinal Microbial Metabolism of Phosphatidylcholine and Cardiovascular Risk. N. Engl. J. Med. 2013, 368, 1575-1584. [CrossRef]

97. Haghikia, A.; Li, X.S.; Liman, T.G.; Bledau, N.; Schmidt, D.; Zimmermann, F.; Krankel, N.; Widera, C.; Sonnenschein, K.; Haghikia, A.; et al. Gut Microbiota-Dependent Trimethylamine N-Oxide Predicts Risk of Cardiovascular Events in Patients with Stroke and Is Related to Proinflammatory Monocytes. Arterioscler. Thromb. Vasc. Biol. 2018, 38, 2225-2235. [CrossRef] 
98. Zhu, W.; Gregory, J.C.; Org, E.; Buffa, J.A.; Gupta, N.; Wang, Z.; Li, L.; Fu, X.; Wu, Y.; Mehrabian, M.; et al. Gut Microbial Metabolite TMAO Enhances Platelet Hyperreactivity and Thrombosis Risk. Cell 2016, 165, 111-124. [CrossRef]

99. Koeth, R.A.; Wang, Z.; Levison, B.S.; Buffa, J.A.; Org, E.; Sheehy, B.T.; Britt, E.B.; Fu, X.; Wu, Y.; Li, L.; et al. Intestinal microbiota metabolism of L-carnitine, a nutrient in red meat, promotes atherosclerosis. Nat. Med. 2013, 19, 576-585. [CrossRef]

100. Wang, Z.; Klipfell, E.; Bennett, B.J.; Koeth, R.; Levison, B.S.; Dugar, B.; Feldstein, A.E.; Britt, E.B.; Fu, X.; Chung, Y.M.; et al. Gut flora metabolism of phosphatidylcholine promotes cardiovascular disease. Nature 2011, 472, 57-63. [CrossRef] [PubMed]

101. Svingen, G.F.T.; Zuo, H.; Ueland, P.M.; Seifert, R.; Loland, K.H.; Pedersen, E.R.; Schuster, P.M.; Karlsson, T.; Tell, G.S.; SchartumHansen, H.; et al. Increased plasma trimethylamine-N-oxide is associated with incident atrial fibrillation. Int. J. Cardiol. 2018, 267, 100-106. [CrossRef]

102. Tang, W.H.; Wang, Z.; Li, X.S.; Fan, Y.; Li, D.S.; Wu, Y.; Hazen, S.L. Increased Trimethylamine N-Oxide Portends High Mortality Risk Independent of Glycemic Control in Patients with Type 2 Diabetes Mellitus. Clin. Chem. 2017, 63, 297-306. [CrossRef] [PubMed]

103. Nie, J.; Xie, L.; Zhao, B.X.; Li, Y.; Qiu, B.; Zhu, F.; Li, G.F.; He, M.; Wang, Y.; Wang, B.; et al. Serum Trimethylamine N-Oxide Concentration Is Positively Associated with First Stroke in Hypertensive Patients. Stroke 2018, 49, 2021-2028. [CrossRef] [PubMed]

104. Yin, J.; Liao, S.X.; He, Y.; Wang, S.; Xia, G.H.; Liu, F.T.; Zhu, J.J.; You, C.; Chen, Q.; Zhou, L.; et al. Dysbiosis of Gut Microbiota with Reduced Trimethylamine-N-Oxide Level in Patients with Large-Artery Atherosclerotic Stroke or Transient Ischemic Attack. J. Am. Heart Assoc. 2015, 4, e002699. [CrossRef]

105. Akhoundzadeh, K.; Vakili, A.; Shadnoush, M.; Sadeghzadeh, J. Effects of the Oral Ingestion of Probiotics on Brain Damage in a Transient Model of Focal Cerebral Ischemia in Mice. Iran. J. Med. Sci. 2018, 43, 32-40.

106. Aronson, D.; Edelman, E.R. Coronary artery disease and diabetes mellitus. Cardiol. Clin. 2014, 32, 439-455. [CrossRef] [PubMed]

107. Yissachar, N.; Zhou, Y.; Ung, L.; Lai, N.Y.; Mohan, J.F.; Ehrlicher, A.; Weitz, D.A.; Kasper, D.L.; Chiu, I.M.; Mathis, D.; et al. An Intestinal Organ Culture System Uncovers a Role for the Nervous System in Microbe-Immune Crosstalk. Cell 2017, 168, 1135-1148.e12. [CrossRef]

108. Lee, S.H. Update on Familial Hypercholesterolemia: Diagnosis, Cardiovascular Risk, and Novel Therapeutics. Endocrinol. Metab. 2017, 32, 36-40. [CrossRef]

109. Jones, B.V.; Begley, M.; Hill, C.; Gahan, C.G.; Marchesi, J.R. Functional and comparative metagenomic analysis of bile salt hydrolase activity in the human gut microbiome. Proc. Natl. Acad. Sci. USA 2008, 105, 13580-13585. [CrossRef]

110. Emoto, T.; Yamashita, T.; Kobayashi, T.; Sasaki, N.; Hirota, Y.; Hayashi, T.; So, A.; Kasahara, K.; Yodoi, K.; Matsumoto, T.; et al. Characterization of gut microbiota profiles in coronary artery disease patients using data mining analysis of terminal restriction fragment length polymorphism: Gut microbiota could be a diagnostic marker of coronary artery disease. Heart Vessel. 2017, 32, 39-46. [CrossRef]

111. Zhu, Q.; Gao, R.; Zhang, Y.; Pan, D.; Zhu, Y.; Zhang, X.; Yang, R.; Jiang, R.; Xu, Y.; Qin, H. Dysbiosis signatures of gut microbiota in coronary artery disease. Physiol. Genom. 2018, 50, 893-903. [CrossRef]

112. Cui, L.; Zhao, T.; Hu, H.; Zhang, W.; Hua, X. Association Study of Gut Flora in Coronary Heart Disease through High-Throughput Sequencing. Biomed. Res. Int. 2017, 2017, 3796359. [CrossRef]

113. Lam, V.; Su, J.; Hsu, A.; Gross, G.J.; Salzman, N.H.; Baker, J.E. Intestinal Microbial Metabolites Are Linked to Severity of Myocardial Infarction in Rats. PLoS ONE 2016, 11, e0160840. [CrossRef]

114. Lam, V.; Su, J.; Koprowski, S.; Hsu, A.; Tweddell, J.S.; Rafiee, P.; Gross, G.J.; Salzman, N.H.; Baker, J.E. Intestinal microbiota determine severity of myocardial infarction in rats. FASEB J. 2012, 26, 1727-1735. [CrossRef] [PubMed]

115. Fialho, A.; Fialho, A.; Kochhar, G.; Schenone, A.L.; Thota, P.; McCullough, A.J.; Shen, B. Association Between Small Intestinal Bacterial Overgrowith by Glucose Breath Test and Coronary Artery Disease. Dig. Dis. Sci. 2018, 63, 412-421. [CrossRef] [PubMed]

116. Brown, J.M.; Hazen, S.L. Microbial modulation of cardiovascular disease. Nat. Rev. Microbiol. 2018, 16, 171-181. [CrossRef] [PubMed]

117. Mayerhofer, C.C.K.; Ueland, T.; Broch, K.; Vincent, R.P.; Cross, G.F.; Dahl, C.P.; Aukrust, P.; Gullestad, L.; Hov, J.R.; Troseid, M. Increased Secondary/Primary Bile Acid Ratio in Chronic Heart Failure. J. Card. Fail. 2017, 23, 666-671. [CrossRef] [PubMed]

118. Akbarzadeh, F.; Homayouni, A. Dairy Probiotic Foods and Coronary Heart Disease: A Review on Mechanism of Action. In Probiotics; Rigobelo, E., Ed.; InTech: London, UK, 2012; pp. 121-128. [CrossRef]

119. Malik, M.; Suboc, T.M.; Tyagi, S.; Salzman, N.; Wang, J.; Ying, R.; Tanner, M.J.; Kakarla, M.; Baker, J.E.; Widlansky, M.E. Lactobacillus plantarum 299v Supplementation Improves Vascular Endothelial Function and Reduces Inflammatory Biomarkers in Men with Stable Coronary Artery Disease. Circ. Res. 2018, 123, 1091-1102. [CrossRef]

120. Raygan, F.; Rezavandi, Z.; Bahmani, F.; Ostadmohammadi, V.; Mansournia, M.A.; Tajabadi-Ebrahimi, M.; Borzabadi, S.; Asemi, Z. The effects of probiotic supplementation on metabolic status in type 2 diabetic patients with coronary heart disease. Diabetol. Metab. Syndr. 2018, 10, 51. [CrossRef]

121. Sawacha, Z.; Guarneri, G.; Avogaro, A.; Cobelli, C. A New Classification of Diabetic Gait Pattern Based on Cluster Analysis of Biomechanical Data. J. Diabetes Sci. Technol. 2010, 4, 1127-1138. [CrossRef]

122. Karadurmus, N.; Sahin, M.; Tasci, C.; Naharci, I.; Ozturk, C.; Ilbasmis, S.; Dulkadir, Z.; Sen, A.; Saglam, K. Potential benefits of hyperbaric oxygen therapy on atherosclerosis and glycaemic control in patients with diabetic foot. Endokrynol. Pol. 2010, 61, 275-279. [PubMed] 
123. Singh, N.; Armstrong, D.G.; Lipsky, B.A. Preventing foot ulcers in patients with diabetes. JAMA 2005, 293, 217-228. [CrossRef] [PubMed]

124. Lepantalo, M.; Apelqvist, J.; Setacci, C.; Ricco, J.B.; de Donato, G.; Becker, F.; Robert-Ebadi, H.; Cao, P.; Eckstein, H.H.; De Rango, P.; et al. Chapter V: Diabetic foot. Eur. J. Vasc. Endovasc. Surg. 2011, 42 (Suppl. 2), S60-S74. [CrossRef]

125. Gourgari, E.; Wilhelm, E.E.; Hassanzadeh, H.; Aroda, V.R.; Shoulson, I. A comprehensive review of the FDA-approved labels of diabetes drugs: Indications, safety, and emerging cardiovascular safety data. J. Diabetes Complicat. 2017, 31, 1719-1727. [CrossRef]

126. Criqui, M.H.; Aboyans, V. Epidemiology of peripheral artery disease. Circ. Res. 2015, 116, 1509-1526. [CrossRef] [PubMed]

127. Boyko, E.J.; Seelig, A.D.; Ahroni, J.H. Limb- and Person-Level Risk Factors for Lower-Limb Amputation in the Prospective Seattle Diabetic Foot Study. Diabetes Care 2018, 41, 891-898. [CrossRef] [PubMed]

128. Nativel, M.; Potier, L.; Alexandre, L.; Baillet-Blanco, L.; Ducasse, E.; Velho, G.; Marre, M.; Roussel, R.; Rigalleau, V.; Mohammedi, K. Lower extremity arterial disease in patients with diabetes: A contemporary narrative review. Cardiovasc. Diabetol. 2018, 17, 138 [CrossRef] [PubMed]

129. Huseini, H.F.; Rahimzadeh, G.; Fazeli, M.R.; Mehrazma, M.; Salehi, M. Evaluation of wound healing activities of kefir products. Burns 2012, 38, 719-723. [CrossRef]

130. Mohseni, S.; Bayani, M.; Bahmani, F.; Tajabadi-Ebrahimi, M.; Bayani, M.A.; Jafari, P.; Asemi, Z. The beneficial effects of probiotic administration on wound healing and metabolic status in patients with diabetic foot ulcer: A randomized, double-blind, placebo-controlled trial. Diabetes Metab. Res. Rev. 2018, 34, e2970. [CrossRef]

131. Sonal Sekhar, M.; Unnikrishnan, M.K.; Vijayanarayana, K.; Rodrigues, G.S.; Mukhopadhyay, C. Topical application/formulation of probiotics: Will it be a novel treatment approach for diabetic foot ulcer? Med. Hypotheses 2014, 82, 86-88. [CrossRef]

132. Covasa, M.; Stephens, R.W.; Toderean, R.; Cobuz, C. Intestinal Sensing by Gut Microbiota: Targeting Gut Peptides. Front. Endocrinol. 2019, 10, 82. [CrossRef] [PubMed]

133. Depommier, C.; Everard, A.; Druart, C.; Plovier, H.; Van Hul, M.; Vieira-Silva, S.; Falony, G.; Raes, J.; Maiter, D.; Delzenne, N.M.; et al. Supplementation with Akkermansia muciniphila in overweight and obese human volunteers: A proof-of-concept exploratory study. Nat. Med. 2019, 25, 1096-1103. [CrossRef]

134. Kumari, M.; Singh, P.; Nataraj, B.H.; Kokkiligadda, A.; Naithani, H.; Azmal Ali, S.; Behare, P.V.; Nagpal, R. Fostering nextgeneration probiotics in human gut by targeted dietary modulation: An emerging perspective. Food Res. Int. 2021, 150, 110716. [CrossRef] [PubMed]

135. Naruszewicz, M.; Johansson, M.L.; Zapolska-Downar, D.; Bukowska, H. Effect of Lactobacillus plantarum 299v on cardiovascular disease risk factors in smokers. Am. J. Clin. Nutr. 2002, 76, 1249-1255. [CrossRef]

136. Simons, L.A.; Amansec, S.G.; Conway, P. Effect of Lactobacillus fermentum on serum lipids in subjects with elevated serum cholesterol. Nutr. Metab. Cardiovasc. Dis. 2006, 16, 531-535. [CrossRef]

137. Laitinen, K.; Poussa, T.; Isolauri, E. Probiotics and dietary counselling contribute to glucose regulation during and after pregnancy: A randomised controlled trial. Br. J. Nutr. 2009, 101, 1679-1687. [CrossRef]

138. Andreasen, A.S.; Larsen, N.; Pedersen-Skovsgaard, T.; Berg, R.M.; Moller, K.; Svendsen, K.D.; Jakobsen, M.; Pedersen, B.K. Effects of Lactobacillus acidophilus NCFM on insulin sensitivity and the systemic inflammatory response in human subjects. Br. J. Nutr. 2010, 104, 1831-1838. [CrossRef]

139. Ejtahed, H.S.; Mohtadi-Nia, J.; Homayouni-Rad, A.; Niafar, M.; Asghari-Jafarabadi, M.; Mofid, V. Probiotic yogurt improves antioxidant status in type 2 diabetic patients. Nutrition 2012, 28, 539-543. [CrossRef]

140. Moroti, C.; Souza Magri, L.F.; de Rezende Costa, M.; Cavallini, D.C.; Sivieri, K. Effect of the consumption of a new symbiotic shake on glycemia and cholesterol levels in elderly people with type 2 diabetes mellitus. Lipids Health Dis. 2012, 11, 29. [CrossRef]

141. Jones, M.L.; Martoni, C.J.; Di Pietro, E.; Simon, R.R.; Prakash, S. Evaluation of clinical safety and tolerance of a Lactobacillus reuteri NCIMB 30242 supplement capsule: A randomized control trial. Regul. Toxicol. Pharm. 2012, 63, 313-320. [CrossRef]

142. Gobel, R.J.; Larsen, N.; Jakobsen, M.; Molgaard, C.; Michaelsen, K.F. Probiotics to adolescents with obesity: Effects on inflammation and metabolic syndrome. J. Pediatric Gastroenterol. Nutr. 2012, 55, 673-678. [CrossRef] [PubMed]

143. Asemi, Z.; Zare, Z.; Shakeri, H.; Sabihi, S.S.; Esmaillzadeh, A. Effect of multispecies probiotic supplements on metabolic profiles, hs-CRP, and oxidative stress in patients with type 2 diabetes. Ann. Nutr. Metab. 2013, 63, 1-9. [CrossRef] [PubMed]

144. Shavakhi, A.; Minakari, M.; Firouzian, H.; Assali, R.; Hekmatdoost, A.; Ferns, G. Effect of a Probiotic and Metformin on Liver Aminotransferases in Non-alcoholic Steatohepatitis: A Double Blind Randomized Clinical Trial. Int. J. Prev. Med. 2013, 4, 531-537.

145. Jung, S.P.; Lee, K.M.; Kang, J.H.; Yun, S.I.; Park, H.O.; Moon, Y.; Kim, J.Y. Effect of Lactobacillus gasseri BNR17 on Overweight and Obese Adults: A Randomized, Double-Blind Clinical Trial. Korean J. Fam. Med. 2013, 34, 80-89. [CrossRef]

146. Sharafedtinov, K.K.; Plotnikova, O.A.; Alexeeva, R.I.; Sentsova, T.B.; Songisepp, E.; Stsepetova, J.; Smidt, I.; Mikelsaar, M. Hypocaloric diet supplemented with probiotic cheese improves body mass index and blood pressure indices of obese hypertensive patients-A randomized double-blind placebo-controlled pilot study. Nutr. J. 2013, 12, 138. [CrossRef] [PubMed]

147. Asemi, Z.; Samimi, M.; Tabassi, Z.; Naghibi Rad, M.; Rahimi Foroushani, A.; Khorammian, H.; Esmaillzadeh, A. Effect of daily consumption of probiotic yoghurt on insulin resistance in pregnant women: A randomized controlled trial. Eur. J. Clin. Nutr. 2013, 67, 71-74. [CrossRef]

148. Asemi, Z.; Khorrami-Rad, A.; Alizadeh, S.A.; Shakeri, H.; Esmaillzadeh, A. Effects of synbiotic food consumption on metabolic status of diabetic patients: A double-blind randomized cross-over controlled clinical trial. Clin. Nutr. 2014, 33, 198-203. [CrossRef] 
149. Mohamadshahi, M.; Veissi, M.; Haidari, F.; Shahbazian, H.; Kaydani, G.A.; Mohammadi, F. Effects of probiotic yogurt consumption on inflammatory biomarkers in patients with type 2 diabetes. Bioimpacts 2014, 4, 83-88. [CrossRef]

150. Lindsay, K.L.; Kennelly, M.; Culliton, M.; Smith, T.; Maguire, O.C.; Shanahan, F.; Brennan, L.; McAuliffe, F.M. Probiotics in obese pregnancy do not reduce maternal fasting glucose: A double-blind, placebo-controlled, randomized trial (Probiotics in Pregnancy Study). Am. J. Clin. Nutr. 2014, 99, 1432-1439. [CrossRef]

151. Ivey, K.L.; Hodgson, J.M.; Kerr, D.A.; Lewis, J.R.; Thompson, P.L.; Prince, R.L. The effects of probiotic bacteria on glycaemic control in overweight men and women: A randomised controlled trial. Eur. J. Clin. Nutr. 2014, 68, 447-452. [CrossRef]

152. Rajkumar, H.; Mahmood, N.; Kumar, M.; Varikuti, S.R.; Challa, H.R.; Myakala, S.P. Effect of probiotic (VSL\#3) and omega-3 on lipid profile, insulin sensitivity, inflammatory markers, and gut colonization in overweight adults: A randomized, controlled trial. Mediat. Inflamm. 2014, 2014, 348959. [CrossRef]

153. Ogawa, A.; Kadooka, Y.; Kato, K.; Shirouchi, B.; Sato, M. Lactobacillus gasseri SBT2055 reduces postprandial and fasting serum non-esterified fatty acid levels in Japanese hypertriacylglycerolemic subjects. Lipids Health Dis. 2014, 13, 36. [CrossRef] [PubMed]

154. Eslamparast, T.; Poustchi, H.; Zamani, F.; Sharafkhah, M.; Malekzadeh, R.; Hekmatdoost, A. Synbiotic supplementation in nonalcoholic fatty liver disease: A randomized, double-blind, placebo-controlled pilot study. Am. J. Clin. Nutr. 2014, 99, 535-542. [CrossRef] [PubMed]

155. Eslamparast, T.; Zamani, F.; Hekmatdoost, A.; Sharafkhah, M.; Eghtesad, S.; Malekzadeh, R.; Poustchi, H. Effects of synbiotic supplementation on insulin resistance in subjects with the metabolic syndrome: A randomised, double-blind, placebo-controlled pilot study. Br. J. Nutr. 2014, 112, 438-445. [CrossRef]

156. Taghizadeh, M.; Asemi, Z. Effects of synbiotic food consumption on glycemic status and serum hs-CRP in pregnant women: A randomized controlled clinical trial. Hormones 2014, 13, 398-406. [CrossRef] [PubMed]

157. Shakeri, H.; Hadaegh, H.; Abedi, F.; Tajabadi-Ebrahimi, M.; Mazroii, N.; Ghandi, Y.; Asemi, Z. Consumption of synbiotic bread decreases triacylglycerol and VLDL levels while increasing HDL levels in serum from patients with type-2 diabetes. Lipids 2014, 49, 695-701. [CrossRef]

158. Simon, M.C.; Strassburger, K.; Nowotny, B.; Kolb, H.; Nowotny, P.; Burkart, V.; Zivehe, F.; Hwang, J.H.; Stehle, P.; Pacini, G.; et al. Intake of Lactobacillus reuteri improves incretin and insulin secretion in glucose-tolerant humans: A proof of concept. Diabetes Care 2015, 38, 1827-1834. [CrossRef]

159. Ostadrahimi, A.; Taghizadeh, A.; Mobasseri, M.; Farrin, N.; Payahoo, L.; Beyramalipoor Gheshlaghi, Z.; Vahedjabbari, M. Effect of probiotic fermented milk (kefir) on glycemic control and lipid profile in type 2 diabetic patients: A randomized double-blind placebo-controlled clinical trial. Iran. J. Public Health 2015, 44, 228-237.

160. Rajkumar, H.; Kumar, M.; Das, N.; Kumar, S.N.; Challa, H.R.; Nagpal, R. Effect of Probiotic Lactobacillus salivarius UBL S22 and Prebiotic Fructo-oligosaccharide on Serum Lipids, Inflammatory Markers, Insulin Sensitivity, and Gut Bacteria in Healthy Young Volunteers: A Randomized Controlled Single-Blind Pilot Study. J. Cardiovasc. Pharm. 2015, 20, 289-298. [CrossRef]

161. Bjerg, A.T.; Kristensen, M.; Ritz, C.; Stark, K.D.; Holst, J.J.; Leser, T.D.; Wellejus, A.; Astrup, A. Four weeks supplementation with Lactobacillus paracasei subsp. paracasei L. casei W8(R) shows modest effect on triacylglycerol in young healthy adults. Benef. Microbes. 2015, 6, 29-39. [CrossRef]

162. Karamali, M.; Dadkhah, F.; Sadrkhanlou, M.; Jamilian, M.; Ahmadi, S.; Tajabadi-Ebrahimi, M.; Jafari, P.; Asemi, Z. Effects of probiotic supplementation on glycaemic control and lipid profiles in gestational diabetes: A randomized, double-blind, placebo-controlled trial. Diabetes Metab. 2016, 42, 234-241. [CrossRef] [PubMed]

163. Madjd, A.; Taylor, M.A.; Mousavi, N.; Delavari, A.; Malekzadeh, R.; Macdonald, I.A.; Farshchi, H.R. Comparison of the effect of daily consumption of probiotic compared with low-fat conventional yogurt on weight loss in healthy obese women following an energy-restricted diet: A randomized controlled trial. Am. J. Clin. Nutr. 2016, 103, 323-329. [CrossRef] [PubMed]

164. Kullisaar, T.; Zilmer, K.; Salum, T.; Rehema, A.; Zilmer, M. The use of probiotic L. fermentum ME-3 containing Reg'Activ Cholesterol supplement for 4 weeks has a positive influence on blood lipoprotein profiles and inflammatory cytokines: An open-label preliminary study. Nutr. J. 2016, 15, 93. [CrossRef] [PubMed]

165. Mobini, R.; Tremaroli, V.; Stahlman, M.; Karlsson, F.; Levin, M.; Ljungberg, M.; Sohlin, M.; Berteus Forslund, H.; Perkins, R.; Backhed, F.; et al. Metabolic effects of Lactobacillus reuteri DSM 17938 in people with type 2 diabetes: A randomized controlled trial. Diabetes Obes. Metab. 2017, 19, 579-589. [CrossRef] [PubMed]

166. Firouzi, S.; Majid, H.A.; Ismail, A.; Kamaruddin, N.A.; Barakatun-Nisak, M.Y. Effect of multi-strain probiotics (multi-strain microbial cell preparation) on glycemic control and other diabetes-related outcomes in people with type 2 diabetes: A randomized controlled trial. Eur. J. Nutr. 2017, 56, 1535-1550. [CrossRef] [PubMed]

167. Tonucci, L.B.; Olbrich Dos Santos, K.M.; Licursi de Oliveira, L.; Rocha Ribeiro, S.M.; Duarte Martino, H.S. Clinical application of probiotics in type 2 diabetes mellitus: A randomized, double-blind, placebo-controlled study. Clin. Nutr. 2017, 36, 85-92. [CrossRef]

168. Mofidi, F.; Poustchi, H.; Yari, Z.; Nourinayyer, B.; Merat, S.; Sharafkhah, M.; Malekzadeh, R.; Hekmatdoost, A. Synbiotic supplementation in lean patients with non-alcoholic fatty liver disease: A pilot, randomised, double-blind, placebo-controlled, clinical trial. Br. J. Nutr. 2017, 117, 662-668. [CrossRef]

169. Hsieh, M.C.; Tsai, W.H.; Jheng, Y.P.; Su, S.L.; Wang, S.Y.; Lin, C.C.; Chen, Y.H.; Chang, W.W. The beneficial effects of Lactobacillus reuteri ADR-1 or ADR-3 consumption on type 2 diabetes mellitus: A randomized, double-blinded, placebo-controlled trial. Sci. Rep. 2018, 8, 16791. [CrossRef] [PubMed] 
170. Kassaian, N.; Feizi, A.; Aminorroaya, A.; Jafari, P.; Ebrahimi, M.T.; Amini, M. The effects of probiotics and synbiotic supplementation on glucose and insulin metabolism in adults with prediabetes: A double-blind randomized clinical trial. Acta Diabetol. 2018, 55, 1019-1028. [CrossRef]

171. Kobyliak, N.; Falalyeyeva, T.; Mykhalchyshyn, G.; Kyriienko, D.; Komissarenko, I. Effect of alive probiotic on insulin resistance in type 2 diabetes patients: Randomized clinical trial. Diabetes Metab. Syndr. 2018, 12, 617-624. [CrossRef]

172. Raygan, F.; Ostadmohammadi, V.; Bahmani, F.; Asemi, Z. The effects of vitamin D and probiotic co-supplementation on mental health parameters and metabolic status in type 2 diabetic patients with coronary heart disease: A randomized, double-blind, placebo-controlled trial. Prog. Neuropsychopharmacol. Biol. Psychiatry 2018, 84, 50-55. [CrossRef] [PubMed]

173. Khalili, L.; Alipour, B.; Asghari Jafar-Abadi, M.; Faraji, I.; Hassanalilou, T.; Mesgari Abbasi, M.; Vaghef-Mehrabany, E.; Alizadeh Sani, M. The Effects of Lactobacillus casei on Glycemic Response, Serum Sirtuin1 and Fetuin-A Levels in Patients with Type 2 Diabetes Mellitus: A Randomized Controlled Trial. Iran. Biomed. J. 2019, 23, 68-77. [CrossRef] [PubMed]

174. Razmpoosh, E.; Javadi, A.; Ejtahed, H.S.; Mirmiran, P.; Javadi, M.; Yousefinejad, A. The effect of probiotic supplementation on glycemic control and lipid profile in patients with type 2 diabetes: A randomized placebo controlled trial. Diabetes Metab. Syndr. 2019, 13, 175-182. [CrossRef] [PubMed]

175. Madempudi, R.S.; Ahire, J.J.; Neelamraju, J.; Tripathi, A.; Nanal, S. Efficacy of UB0316, a multi-strain probiotic formulation in patients with type 2 diabetes mellitus: A double blind, randomized, placebo controlled study. PLoS ONE 2019, 14, e0225168. [CrossRef] [PubMed]

176. Palacios, T.; Vitetta, L.; Coulson, S.; Madigan, C.D.; Lam, Y.Y.; Manuel, R.; Briskey, D.; Hendy, C.; Kim, J.N.; Ishoey, T.; et al. Targeting the Intestinal Microbiota to Prevent Type 2 Diabetes and Enhance the Effect of Metformin on Glycaemia: A Randomised Controlled Pilot Study. Nutrients 2020, 12, 2041. [CrossRef]

177. Brussow, H. Problems with the concept of gut microbiota dysbiosis. Microb. Biotechnol. 2020, 13, 423-434. [CrossRef]

178. Koh, A.; Backhed, F. From Association to Causality: The Role of the Gut Microbiota and Its Functional Products on Host Metabolism. Mol. Cell 2020, 78, 584-596. [CrossRef] 